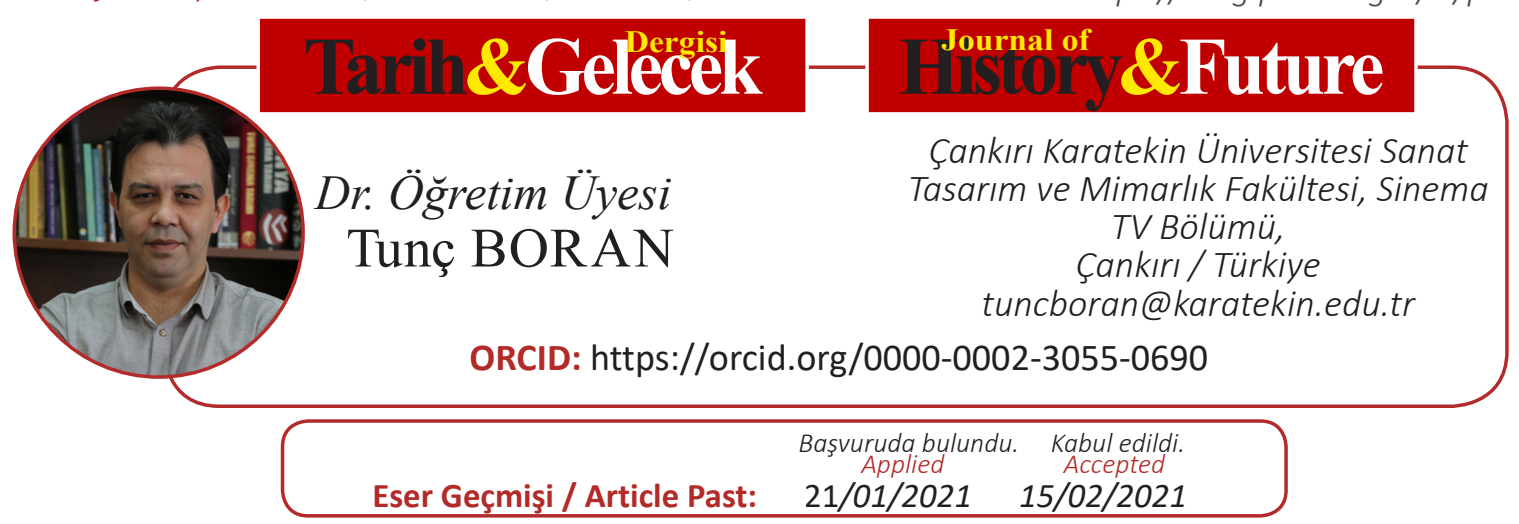

Araştırma Makalesi

DOI: http://dx.doi.org/10.21551/jhf.866200

Research Paper

Orjinal Makale / Orginal Paper

\title{
Demokrat Parti’nin “Atatürk Sevgisi” (1954) Belgesel Filmi
}

\section{Democratic Party's “Atatürk Sevgisi” (1954) Documentary Film}

$\ddot{\mathrm{O} z}$

Mustafa Kemal Atatürk'ün sağlığında veyahut ölümünün ardından hayatını konu alan belgesel niteliğinde bir film yapılmamıştır. Atatürk'ün hayatına dair ilk belgesel film, 1954 yılında Demokrat Parti döneminde yapılmıştır. "Atatürk Sevgisi” adını taşıyan filmin yönetmeni Münir Hayri Egeli' dir. Filmin yapımında ve finansmanında Demokrat Parti özellikle dönemin Cumhurbaşkanı Celal Bayar etkili olmuştur. Atatürk'ün sağlığında çekilen arşiv görüntülerinden oluşan “Atatürk Sevgisi” filmi, derleme bir belgeseldir. Film, 2 Mayıs 1954 Milletvekili Genel Seçimlerinden bir hafta evvel tüm Türkiye' de sinemalarda gösterime girmiştir. Bu nedenle “Atatürk Sevgisi” Demokrat Parti'nin seçim propaganda filmi olarak da değerlendirilmiştir. Ancak film propaganda çalışması olmasının yanı sıra Demokrat Parti'nin Atatürk’e ve Atatürkçülüğe bakışını da yansıtmaktadır. Bu çalışmada, Atatürk Sevgisi filminin yapım süreci aktarılacaktır. Demokrat Parti’nin temsil ettiği Atatürkçülüğün sağ yorumunun izleri Atatürk Sevgisi filminde araştırılacaktır.

Anahtar Kelimeler: Belgesel Film, Atatürk Belgeseli, Demokrat Parti, Atatürkçülük, Propaganda

\begin{abstract}
There was no documentary film about the life of Mustafa Kemal Ataturk in his health or after his death. The first documentary film about Ataturk's life was made in 1954 during the Democratic Party. The director of the film titled "Ataturk Sevgisi" is Münir Hayri Egeli. The Democratic Party and especially by then-President Celal Bayar were particularly influential in the production and financing of the film. The film "Ataturk Sevgisi", which consists of archival images taken in Ataturk's health, is a compilation documentary. The film was released in movie theaters all over Turkey a week before the May 2, 1954 Parliamentary General Elections. Therefore "Atatürk Sevgisi” was also considered as the election propaganda film of the Democratic Party. However, in addition to being a propaganda study,
\end{abstract}

ATIF: BORAN, Tunç, "Demokrat Parti'nin “Atatürk Sevgisi" (1954) Belgesel Filmi”, Tarih ve Gelecek Dergisi, 7/1 (Mart 2021), s. $(98-118)$

CITE: BORAN, Tunç, "Democratic Party's "Atatürk Sevgisi" (1954) Documentary Film", Journal of History and Future, 7/1 (March 2021), pp. (98-118) 
the film also reflects the Democratic Party's view of Ataturk and Ataturkism. In this study, the production process of Ataturk Sevgisi will be transferred. Traces of the right-wing interpretation of Ataturkism represented by the Democratic Party will be explored in the film Ataturk Sevgisi.

Keywords: Documentary Film, Ataturk Documentary, Democratic Party, Ataturkism, Propaganda

\section{Giriş}

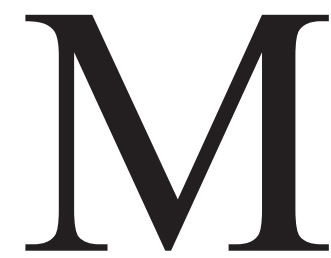

ustafa Kemal Atatürk'ün sağlığında hayatını, mücadelesini konu alan kurmaca veyahut belgesel niteliğinde bir film yapılmamıştır. Ancak elbette Atatürk'ün pek çok kez gündelik hayatın içinde, resmi toplantılarda, yurtiçi gezilerinde film kamerası ile görüntüsü alınmıştır. Mustafa Kemal Atatürk'ün film kamerası ile görüntüsünün ilk kez ne zaman ve nerede alındığını bilemesek de siyasi lider olarak yükseldiği, dış ve iç kamuoyunda tanınırlığının arttığı Milli Mücadele döneminden itibaren film kamerası ile tanıştığını iddia etmek hatalı bir tespit olmaz. Harp Okulu günlerinden itibaren Kurtuluş Savaşına dek sayıca çok fazla olmamakla birlikte Mustafa Kemal Atatürk'ün çekilmiş fotoğrafları vardır. ${ }^{1}$ Hareketli görüntüsü ise Milli Mücadelenin zaferle sonuçlandığı yıl olan 1922 yılında yoğunlaşmaktadır. Tarihi bir özne olarak yükselmesi ile objektiflerin Mustafa Kemal Atatürk’e dönmesi doğaldır. Milli Mücadelenin muzaffer lideri olarak tarih sahnesine çıkışı ile kameraların odağında yer alması eş zamanlı gerçekleşmiştir. İzmir'in kurtuluşu esnasında ve sonrasında Mustafa Kemal Atatürk, beyazperdede görünmeye başlamıştır. Bu görünürlüğü özellikle Ordu Film Çekme Merkezi ve Kemal Film’in çalışmaları sağlamıştır. Mütareke döneminde düşmanın eline geçmemesi için Malûl Gaziler Cemiyetine devredilen Merkez Ordu Sinema Dairesine ait sinema ekipmanları, Milli Mücadelenin kazanılmasına yakın 1922'de Ankara'ya getirilerek Ordu Film Çekme Merkezi kurulmuştur. Ordu Film Çekme Merkezi tarafından "İzmir Zaferi, " "Dumlupınar Vekayi’i, " "İzmir Nasıl İstirdat Edildi? " "İzmir'in İşgali, " “İzmir'deki Yunan Fecayii," “İzmir Yanıyor," “Gazi’nin İzmir'e Gelişi ve Karşılanması”" isimli aktüel belge filmler çekilmiştir. Aynı dönemde Türkiye’nin ilk özel film yapım şirketi Kemal Film, aralarında “Gazi Mustafa Kemal Paşa'nın İzmit Cephesini Teftişi” adlı filmin de olduğu 47 haber filmi üretmiştir. ${ }^{2}$ Amacı, Yunan Ordusunun kaçarken Batı Anadolu'da yaptığı katliamları, vahşeti tespit etmek ve Türk Ordusunun zaferini duyurmak olan filmler, elbette o zaferin mimarı olan Mustafa Kemal Atatürk'ü de göstermektedir.

Zafer ile birlikte yabancı prodüksiyon ve ajanslarının kameraları da Ankara'ya ve Atatürk'e dönmüştür. Fransa'nın ünlü yapım şirketi Gaumont, Amerikan Patenior Sinematograf Şirketi temsilcisi J. Ecrol, başka bir Amerikan şirketi Vizografik Pikers bu dönemde Türkiye'de aktüel çekim yapma talebinde bulunan yapımcılardan bazılarıdır. Türkiye'de o tarihlerde çekim yapma taleplerinden biri de Amerikan Donanmasından gelmiştir. Amerikan Donanmasından Teğmen Louis

1 Kansu Şarman, “1909-1919 Arşiv Fotoğraflarından Genç Mustafa Kemal,” Atlas Tarih Kurtuluş Savaşı Özel Say1s1 2, Say1 2020/01, s.24-31.

2 Erman Şener, Kurtuluş Savaşı ve Sinemamız, Dizi Yayınları, İstanbul, 1970, s. 22-26; Nijat Özön, İlk Türk Sinemacısı Fuat Uzkınay, Türk Sinematik Derneği Yayınları, İstanbul, 1970, s.37. 
de Rochemont, İzmir'de, Ankara'da ve Anadolu'da çekimler yapmıştır. ${ }^{3}$ Louis de Rochemont, daha sonra 1935 senesinde ünlü haber dizisi The March of Time'ın yapımcısı olmuştur. Ünlü Pathe film de bu dönemde Anadolu'nun ve Atatürk'ün aktüel görüntülerini çekmiştir. ${ }^{4}$ Mustafa Kemal Atatürk'ü ilk defa sesli olarak görüntüsünü alan da yabancı bir ajans olmuştur.11 Kasım 1930 günü, Gazi Orman Çiftliğinde Fox Movietone News tarafindan çekilen filmde, Atatürk'ün yanı sıra dönemin Amerikan Büyükelçisi Joseph Grew'de yer almıştır. 10 kısımdan oluşan filmde, Çiftlikteki çalışmalar tanıtılmaktadır. Ancak filmin en dikkat çekici yeri Atatürk'ün Amerikalılara seslendiği bölümdür. Konuşmasında "Türk milleti tabiat itibariyle demokrattır” diyen Atatürk'ün ilk defa sesli görüntüsü kaydedilmiştir. ${ }^{5}$

Cumhuriyetin ilanından sonra Atatürk'ün devlet başkanı olarak da yaptığı yurt içi gezileri de kamera ile takip edilmiştir. 1924'te Kemal Filmin kapanması ile uzun bir süre tek özel prodüksiyon şirketi olarak kalan İpek Filmin gelen talepler üzerine nadiren Atatürk'ü kameraya aldı̆̆ 1 bilinmektedir. Atatürk'ün görüntülendiği yurt içi gezileri, 1923 ve 1924 yılında yoğunlaşmaktadır. Muhtemelen bu gezileri, Ordu Film Çekme Merkezi kameramanları kayıt altına almıştır. 1930 yılına değin A tatürk'ün yurt içi gezilerinin istikrarlı bir şekilde kamera ile kaydedilmediği düşünülmektedir. 1933 senesinde Türkiye'de sinema üzerine bir rapor hazırlayan Eugene M. Hinkle de aynı duruma işaret ederek bu dönemde Atatürk'ün ender olarak filmlerde görüldügüüü kaydetmektedir. Hinkle, bunun nedeninin Atatürk'ün tanıtım faaliyetlerine ilgisizliğinden kaynaklandığını iddia etmektedir. ${ }^{6}$ Ancak Atatürk'ün çekim ve tanıtım faaliyetlerine bütünüyle ilgisiz kalmadığını gösteren filmler de mevcuttur. Örnek bir çiftlik olması için kurulan Gazi Orman Çiftliğinde yapılan çalışmaları tanıtmak maksadıyla Atatürk tarafından Ferit İbrahim Özgürar film çekimi için görevlendirilmiştir. 1929 yılının ilkbaharında Gazi Orman Çiftliği ile ilgili 1.000 metre uzunluğu sessiz film hazırlanmış ve film, Parti ve kamu yararına çalışan dernekler vasıtasıyla 1929 yılı Eylül ayında ülke çapında gösterilmiştir. ${ }^{7} 1930$ yılının sonunda Ankara Kulüp Sineması Müdürü Kenan Erginsoy, Atatürk'ün çıkacağı uzun yurt içi gezisini filme çekmesi için davet edilmiştir. Erginsoy’un ifadesi ile o tarihte Cumhurbaşkanlığına film kaydedicisi alınmıştır. 17 Kasım 1930-3 Mart 1931 arasında fasılalarla gerçekleşen ve Atatürk’ün halkın sorunlarını yakından gözlemlediği uzun gezi, Erginsoy tarafından film makinesiyle kaydedilmiştir. 1932 senesine Ankara Halkevi sinema mütehassısı olarak işe alınan Erginsoy, o tarihten itibaren Atatürk'ün gezilerini ve faaliyetlerini takip etmiş ve kameraya kaydetmiştir. ${ }^{8}$ Hakikaten de 1930 yılından itibaren Atatürk’ün aktüel çekimleri daha yoğundur.

Aktüel çekimlerin yanı sıra Atatürk'ün sağlığında yakın tarihi veya aktüel olayları konu alan belgeseller de yapılmıştır. 1930 senesinde Fuat Uzkınay’ın yönetiminde “İzmir Zaferi” adlı belge film "İstiklal" adıyla genişletilmeye başlanmıştır. Film, 1934 senesinde İran Şahı Rıza Pehlevi'nin ziyaretinde gösterilmiştir. Bu gösterimden sonra Atatürk'ün emri ile 3 kısımdan

3 Ali Özuyar, Türk Sinema Tarihinden Fragmanlar (1896-1945), Phoenix Yayınevi, Ankara, 2013, s.221225.

4 Enis Dinç, Performing Modernity: Atatürk On Film (1919-1938), University of Amsterdam, Yayınlanmamış Doktora Tezi, 2016, s.61-69.

5 Rifat Bali, The Turkish Cinema In The Early Republican Years, The Isis Press, İstanbul, 2007, s. 13-20.

6 Eugene M. Hinkle, "Modern Türkiye'de Sinema," Kebikeç Dergisi, Sayı:28, s.97.

7 Ali Özuyar, “Gazi’nin Sineması Köşk'ün Beyazperdesinde,” Atlas Tarih Kurtuluş Savaşı Özel Sayısı, 2020/01, s.122

8 Cumhuriyet Arşivi, 490-1-0-0/384-1625-2-s.3-4-5-6-16; Kenan Harun, "Ata’nın Emrindeki Adam Anlatıyor," 20. Asır Dergisi, Sayı:13, 8 Kasım 1952, s.8,30. 
ibaret olan "İstiklal”" filmini genişletme çalışmasına devam edilmiştir. Bu genişletme çalışması sırasında, Ordu Film Çekme Merkezi ve Kemal Film tarafından çekilen Kurtuluş Savaşının belge filmlerinden yararlanılmış, yeniden canlandırma sahneleri çekilerek 1936 senesinde "istiklal" filmi 12 kısma çıkartılmıştır. Atatürk'ün ölümünden sonra cenaze töreni de eklenerek 13 kısma çıkartılan "İstiklal" filmi nihayet 1942'de tamamlanmıştır. ${ }^{9}$ Bir diğer belgesel film, Cumhuriyetin 10. Yılı münasebetiyle 1933 senesinde Matbuat Umum Müdürlüğü tarafindan Sovyet yönetmen Sergey Yutkeviç'e hazırlatılmıştır. Filmde, Milli Mücadelede ve Cumhuriyetin ilk yıllarında Ankara'nın rolü anlatılmış, Cumhuriyetin Onuncu Yıl etkinliklerine ve Atatürk'ün nutkuna yer verilmiştir. Belgesel için Türkiye'de 120.000 metrelik film çekilmiştir. 2.400 metrelik "Türkiye'nin Kalbi Ankara” adını taşıyan belgesel film, Şubat 1934'te tamamlanmıştır. Mart ve Nisan 1934'te film, başta Atatürk ve İnönü olmak üzere Türk yetkilere izletilmiştir. Türk-Sovyet ilişkilerinin iyi niyet nişanesi sayılan film, Türkiye dışında Moskova ve Leningrad'da da gösterilmiştir. ${ }^{10}$ Muhtemeldir ki "Türkiye'nin Kalbi Ankara" filminin etkisiyle o güne kadar film ithalatçısı olan Ha-Ka Film, 1934'te ünlü Rus kadın yönetmen Esfir Shub'a “Türkiye Yürüyor" adını taşıyan belgesel film sipariş etmiş̧ir. Ankara, İstanbul ve İzmir'de çekilen aktüel görüntülerle arşiv görüntülerinin bir araya getirilmesi ile meydana gelen film, ancak üç yıl sonra 1937 y1lında "Türk İnkılâbında Terakki Hamleleri” adıyla gösterime çıkmıştır. Nijat Özön'e göre film, üç yıllık bir çalışmanın titizliğinde olmadığı gibi derleme belgesel filmin ünlü ismi Esfir Shub'un elinden geçtiğini gösteren bir yönü de yoktur. Film, daha evvel CHP'de kameraman olarak görev yapan Kemal Necati Çakuş tarafından meydana getirilmiştir. Tarih dersinin kuruluğunu taşımasına rağmen Özön'e göre, “Türk İnkllâbında Terakki Hamleleri” filmi Türkiye'nin yakın tarihine dair en derli toplu montaj filmidir. ${ }^{11}$ Atatürk'ün sağlığında yakın döneme dair hazırlanan dördüncü ve son film bir Amerikan yapımıdır. Bu fillmi, serbest fotoğrafçı, belgesel film yapımcısı Julien Bryan çekmiştir. Bryan, profesyonel kariyerinde farklı kültürleri, önemli olayları ve insanları resmettiği çok sayıda fotoğraf ve film çekmiştir. Çektiği filmleri, "gezi dersleri" veya "resimli halka açı konferanslar" olarak adlandırılan toplantılarda kamuoyu ile paylaşmaktadır. Bu gezi dersleri, 1930'ların sonlarına kadar popüler ve saygın bir eğlencedir. Bryan, gezi derslerini kolejlerin ve üniversitelerin konferans salonlarında, kulüpler ve film topluluklarında, enstitülerde ve hatta Beyaz Saray'da gerçekleştirmiştir. Bu gezi derslerinin yanı sıra "The March of Time" gibi popüler haber dizilerine çektiği filmleri satmaktadır. Julien Bryan, 1936 senesinde yaşanan köklü değişimi ve değişimin karizmatik liderini görüntülemek maksadıyla Türkiye'ye gelmiştir. 1936 yılının Eylül ayında İstanbul Florya Köşkünde Byran, Atatürk'ü iki gün boyunca görüntülemiştir. Bu iki günlük sürede Bryan, Atatürk'ün yaklaşık iki yüz fotoğrafını ve bin ila bin iki yüz fit $(304,8$ metre- 365,7 metre) 35 mm filmini çekmiştir. Bryan, Atatürk'ü çektikten sonra Türkiye'de hayatın hemen her alanını kapsayan yirmi bin fitlik (6096 metre) siyah beyaz 35 mm'lik negatif film kaydetmiştir. Bryan, çektiği bu ham görüntülerden "Reborn Turkey" (Yeni Türkiye) ${ }^{12}$ adl1 90

9 Nijat Özön, Türk Sinema Tarihi, Dünden Bugüne 1896-1960, Artist Yayınları, İstanbul, 1962, s.232-233; Nijat Özön, Türk Sineması Kronolojisi 1895-1966, Bilgi Yayınevi, 1968, s. 65; Erman Şener, Kurtuluş Savaşı ve Sinemamız, Dizi Yayınları, İstanbul, 1970, s. 28-31.

10 Süleyman Beyoğlu, Imparatorluktan Cumhuriyete Türk Sineması (1895-1939), Dergâh Yayınları, İstanbul, 2018,s. 124.

11 Nijat Özön, Türk Sinema Tarihi, Dünden Bugüne 1896-1960, Artist Yayınlar1, İstanbul, 1962, s.236; Hakan Aytekin, Türkiye'de Toplumsal Değişme ve Belgesel Sinema, BSB Yayınları, İstanbul, 2017, s.80. 
dakika uzunluğunda sessiz bir film meydana getirmiştir. Bu film, Atatürk’ü gündelik hayatın sadeliği ve samimiyeti ile tasvir etmektedir. Filmde, Atatürk'ün özel hayatından sahneler vardır. Atatürk'ün evlatlık küçük kızı Ülkü’yle vakit geçirmesi, oynaması, O’na okuma yazma öğretmesi gösterilmektedir. Atatürk'ün denizde yüzmesini, yüzdükten sonra kendini kurulaması ve plajda mayosu ile dinlendiğini gösteren sahneler "Reborn Turkey” filminin en bilinen kısımlardır. "Rebon Turkey” filmi; kulüpler, üniversiteler, enstitüler ve müzelerin yanı sıra elçiliklerde ve Beyaz Saray da dahil olmak üzere ABD'deki çeşitli yerlerde gösterilmiştir. Beyaz Saray'da özel gösterimde filmi izleyen Başkan Franklin D. Roosevelt, ülkesini güçlü, modern bir ulus devlete dönüştürerek büyük başarılara imza atmasına karşın filmde, kendisini büyük bir içtenlik ve alçak gönüllülükle sunan Atatürk’ten etkilenmiştir. Filmi izledikten sonra Roosevelt, Atatürk'e olağan resmi yazışmaları aşan sıcak, dostane ve kişisel bir mektup göndermiştir. Atatürk de aynı samimiyette bir mektupla Roosevelt'e karşılık vermiştir. Ayrıca Julien Bryan'ın görüntülerinden ünlü haber dizisi The March of Time, "Father of All Turks" (Tüm Türklerin Babası) adlı altı dakika uzunluğunda bir haber filmi hazırlamıştır. İlk gösterimi 19 Şubat 1937'de yapılan haber filmi, ABD ve Avrupa'da gösterilmiştir. ${ }^{13}$

Atatürk'ün sağlığında üretilen dört filmin de teması Atatürk'ün hayatı olmamıştır. "İstiklal”, filmi Kurtuluş Savaşı'na odaklanırken diğer üç film “Türkiye’nin Kalbi Ankara” "Türk İnkılâbında Terakki Hamleleri” ve "Reborn Turkey” Türkiye'nin Cumhuriyet ile geçirdiği değişimi anlatmıştır. $\mathrm{Bu}$ filmler, elbette Kurtuluş Savaşı ve genç Cumhuriyetin liderine ağırlıklı olarak yer verseler de Atatürk'ün biyografisini anlatan yapımlar olmamıştır.

Atatürk’ün ölümünün ardından İnönü devrinde 1941 yılında Matbuat Umum Müdürlüğünde bir sinema kolu kurulmuştur. Matbuat Umum Müdürlüğü o tarihten itibaren törenler, Cumhurbaşkanın gezileri, ziyaretler, at yarışları gibi konularda düzensiz aralıklarla haber filmleri üretmiştir. ${ }^{14}$ Ancak bu dönemde Atatürk'ün hayatına dair veyahut yakın tarih ile ilgili belgesel film gerçekleştirilmemiştir. Atatürk'ün sağlığında çekilen gerek kısa aktüel filmler gerekse de "İstiklal," "Türkiye’nin Kalbi Ankara," "Türk İnkllâbında Terakki Hamleleri" ve "Reborn Turkey” filmleri daha sonra hazırlanan derleme belgesel fillmler için önemli bir görüntü ve arşiv kaynağına dönüşmüşlerdir.

Nihayet 1954 senesinde Demokrat Parti iktidarında, “Atatürk Sevgisi” adını taşıyan Atatürk’ün hayatına odaklandığını iddia eden ilk derleme belgesel film hazırlanmıştır. Film üretimi, ideolojik bir etkinliktir. Film, yapımcı, senarist ve yönetmenin ideolojisi ile şekillenir. ${ }^{5}$ "Atatürk Sevgisi" filminde yapımcı açıklıkla ifade edilmese de Demokrat Parti'dir. Filmler üretildikleri dönemin toplumunun ruh durumunu yansıttıkları gibi zamanın egemen düşünce ve dünya görüşünü de ifade ederler. ${ }^{16}$ Tarihin yeniden perdeye taşınmasında egemen olan görüş, geçmişi yeniden şekillendirir ya da inşa eder. Bu bağlamda çalışmanın amac1, "Atatürk Sevgisi” filmine yansıyan Demokrat Parti'nin Atatürk'e ve Atatürkçülüğe bakışını araştırmaktır. Çalışmada, Demokrat Parti’nin

13 Enis Dinç, Performing Modernity: Atatürk on Film (1919-1938), University of Amsterdam, Yayınlanmamış Doktora Tezi, 2016, s.138-157.

14 Nijat Özön, Türk Sinema Tarihi, Dünden Bugüne 1896-1960, Artist Yayınları, İstanbul, 1962, s.234.

15 Lale Kabadayı, Film Eleştirisi Kuramsal Çerçeve ve Sinemamızdan Örnek Çözümlemeler, Ayrıntı Yayınları, İstanbul, 2013, s.63-64.

16 Zafer Özden, Film Eleştirisi Film Eleştirisinde Temel Yaklaşımlar ve Tür Filmi Eleştirisi, İmge Kitapevi, Ankara, 2014, s.120. 
"Atatürk Sevgisi" filminde geçmişi şekillendirme ve geçmişi yeniden inşası ortaya konacaktır. Ancak öncelikle Demokrat Parti'nin Sağ-Kemalizm veya Sağ-Atatürkçülük olarak adlandırılan Atatürkçülük yorumunun incelenmesi gerekmektedir.

\section{Demokrat Parti’nin Atatürkçülük Yorumu}

Türkiye Cumhuriyeti'nin kurucusu Mustafa Kemal Atatürk'ün milliyetçilik ve çağdaşlaşma anlayışı ile O'nun inkılâp ve ilkeleri doğrultusunda oluşan Atatürkçülük, Türk devletinin kurucu ideolojisidir. Aynı zamanda Atatürkçülük, Türk siyasi düşünce dünyasının merkezi akımıdır. Atatürkçülük, merkezi konumunu sürdürmesini totaliter siyasal tahakkümü sayesinde değil siyasal düşünce boyutundaki güç ve etkinliğine borçludur. Asli ögeleri milliyetçilik ve medeniyetçilik olan Atatürkçülük, toplumun büyük bölümünün paylaştığı ulusal modernleşme ülküsünün siyasal bir duruşa dönüştüğü bir ideolojidir. Uluslaşma ve modernleşme sorunsalı sürekli gündeminde olan Türkiye'de siyasal bir duruş olarak Atatürkçülüğün merkezi konumunu koruması şaşırtıcı değildir. Atatürkçülük, birçok siyasal düşünce akımı gibi, tek bir tanıma ve tek bir anlayışa indirgenemez. Bu nedenle farklı farklı Atatürkçülük akımlarından bahsetmek daha doğrudur ve doğaldır. Bunlar sağ veya sol Atatürkçülük, devletçi veya liberal Atatürkçülük, muhafazakâr veya reformcu Atatürkçülük olarak diğer siyasal düşün akımlarıyla eklemlenirler. ${ }^{17}$ Bu ayrımlardan önce kurucu siyasi düşünceyi adlandırmada dahi farklılıklar bulunduğuna dikkat çekmek gerekir. Aynı siyasi düşünceyi kimileri Kemalizm, kimileri de Atatürkçülük olarak adlandırmaktadır. Elbette Kemalizm ve Atatürkçülük eş anlamlı kavramlardır. Netice itibariyle her iki kavramda aynı kişinin, Mustafa Kemal Atatürk'ün görüşlerine dayanmaktadır. İçerik olarak bu iki kavram aynı olmakla birlikte kavramların yorumlanışında farklılıklar bulunmaktadır. İlk ortaya çıkan kavram Kemalizm'dir. Kemalizm ifadesini ilk kullananlar Batılılar olmuştur. Henüz Kurtuluş Savaşı sırasında Mustafa Kemal Paşa'yı takip edenleri ve fikriyatlarını ifade etmek için Batılılar, Kemalist ifadesini kullanmıştır. Batılıları takiben Milli Mücadeleye muhalif İstanbul basını ve İstanbul Hükümeti de rencide edici bir tavırla Kemali veya Kemalist ifadesini kullanmışlardır. Celali isyancılarına benzetilen ve çete hareketi olarak aşağılanan Kemalist hareket, kazanılan zafer ile haklı bir ün ve güçlü bir meşruiyet kazanmıştır. Milli Mücadele sonrasında kurulan Cumhuriyet ve inkılâplar ile Kemalizm'den bu defa siyasal bir düşünce olarak bahseden yine Batılılar olmuştur. Kemalizm'in Parti ideolojisi haline dönüşümü ise 1927 yılında Cumhuriyet Halk Partisi İkinci Büyük Kurultayı'nda Kemalizm'in dört ilkesinin -Cumhuriyetçilik, Halkçılık, Milliyetçilik, LaiklikParti'nin prensipleri olarak kabul edilmesiyle başlamıştır. 1931 yılında yapılan Cumhuriyet Halk Partisi İkinci Büyük Kurultayında ise Devletçilik ve Devrimcilik ilkelerinin kabulü ile Kemalizm'in ilke sayısı altıya yükselmişsir. 6 ilkenin Parti programında yer almasına karşın "Kemalizm" ifadesi ancak 1935 yılında Parti'nin Dördüncü Büyük Kurultayı'nda kabul edilen Parti programının giriş bölümünde yer almıştır. ${ }^{18}$ Ülke içinde inkılâp hareketini izah etme, Kemalizm ideolojisinin çerçevesini oluşturma ve adlandırma çalışmaları, 1930'lu yıllardan itibaren başlamıştır. Tek parti rejiminin kurumsallaşması sürecinde inkılâp hareketini doktrinleştirmeye ve sistemleştirmeye çalışan girişimler olmuştur. Örneğin, Kadro Dergisi, Türk inkılâbının ideolojisini sistematik bir

17 “Sunuş,” Modern Türkiye’de Siyasi Düşünce Cilt: 2 Kemalizm, İletişim Yayınları, İstanbul, 2006, s. 1415.

18 Mustafa Albayrak, “Kemalizm'in Düşünsel Temelleri ve Tarihsel Oluşumu,” Atatürk Araştırma Merkezi Dergisi, Cilt: 26, Say1: 77, 2010, s.309-315 
şekilde geliştirme işini gönüllü olarak üstlenmiştir. ${ }^{19}$ Tarihsel materyalizmi bir yöntem olarak benimseyen kısa ömürlü Kadro Dergisi, Atatürkçülüğün ilk sol yorumu veya "Sol Kemalizm'in" ilk örneği olarak kaydedilmiştir. ${ }^{20}$ Kadro Dergisine yönelik tepkiler ve eleştiriler, Kemalizm'in farklı yorumlarının uç vermeye başladığını göstermiştir. Tek Parti yönetimini kurumsallaştırmaya çalışan ve Türk İnkılâbının ideolojisini yapma görevinin Parti’ye ait olduğunu savunan Recep Peker önderliğindeki grup, Kadro Dergisini tehlikeli bir faaliyet olarak algılamıştır. Öte yandan İşs Bankası'nın temsil ettiği varsayılan sermaye çevreleri de Kadro Dergisi'nin devletçilik önerilerini komünizm ve kolektivizm olarak yorumlamışlar ve dergiyi zararlı bir yayın olarak eleştirmişlerdir. ${ }^{21}$ Kadro Dergisine yönelik eleştirilerin Recep Peker'in temsil ettiği "Otoriter Kemalizm”den ve sermaye gruplarının oluşturduğu "Liberal Kemalizm"den gelmesi dikkat çekicidir. Ayrıca henüz bu erken dönemde, Peyami Safa'nın 1938'de yayınlanan “Türk İnkılâbına Bakışlar” kitabını da Kemalizm'i muhafazakâr bir modernizm olarak okuma girişimi olarak kaydetmek gerekir. ${ }^{22}$

Gazi Mustafa Kemal, 1934 senesinde "Atatürk" soyadını almasına karşın sağlığında "Atatürkçülük" kavramı kullanılmamış, Cumhuriyetin ideolojisi Kemalizm ile tarif edilmeye devam edilmiş, bu dönemde Kemalizm başlıklı yayınlar bilakis artmıştır. 1935 senesinde Parti programında "kavram” olarak yer aldıktan sonra Atatürk'ün sağlığında İsmet İnönü’nün ve Celal Bayar'1n Kemalizm sözcügünü sık sık kullanmaları kavramın resmiyet ve yaygınlık kazandığını göstermektedir. ${ }^{23}$ “Atatürkçülük” sözcüğü ise Levent Köker’e göre, 1940’lı yılların ilk yarısında Milli Şef döneminde sakıncasız muhalefet etmenin bir yolu olarak ortaya çıkmıştır. "A "Atatürkçülük" ifadesinin Atatürk öldükten sonra ortaya "atıldığına" dikkat çeken Atilla İlhan'a göre ise, "İnönü Cumhuriyeti” olarak adlandırdığı Milli Şef döneminde "Atatürkçülük” sözcüğünün iktidarın sosyal, siyasal tavır ve tutumuna yakışan bir etiket olarak çıktığını iddia etmektedir. Söylemeye gerek yok, Atilla İlhan, Atatürkçülüğü Kemalizm'in yozlaştırılması olarak görmektedir. ${ }^{25}$ İkinci Dünya Savaşı'nın ardından çok partili hayat ile Kemalizm'in yerine Atatürkçülük kavramı tercih edilmeye başlanmıştır. Demokrat Parti, Atatürkçülük ifadesini kullanırken Cumhuriyet Halk Partisi 1953 Kurultayı'nda Parti programında yer alan Kemalizm terimini “Atatürk Yolu" ifadesi ile değiştirmiştir. ${ }^{26} 1960$ 'lı y1llardan itibaren ise sol siyasi düşünce ve örgütlenmelerin Kemalizm'i, milliyetçi-muhafazakâr sağ düşünce ve örgütlenmeler ise Atatürkçülük sözcügünü tercih etmişlerdir. Kemalizm ve Atatürkçülük sözcükleri sıkça farklı ve çatışan yorumlara konu

19 Temuçin F., Ertan, "Beklentiler, Hayal Kırıklıkları ve Aydınlar (Kadro-Forum-Yön)," Türk Yurdu Dergisi, Cilt:18 , Say1:134, Ekim 1998, s.145.

20 Faruk Alpkaya, "Bir 20. Yüzyıl Akımı: Sol Kemalizm,” Modern Türkiye’de Siyasi Düşünce Cilt: 2 Kemalizm, İletişim Yayınları, İstanbul, 2006, s. 477-478

21 Temuçin F., Ertan, “Kadro Dergisi Niçin Kapandı?” Atatürk Dergisi, Cilt:3, Sayı:4, Temmuz 2003, s.2527.

22 Tanıl Bora, Yüksel Taşkın, "Sağ Kemalizm,” Modern Türkiye’de Siyasi Düşünce Cilt: 2 Kemalizm, İletişim Yayınları, İstanbul, 2006, s. 530.

23 Mustafa Albayrak, "Kemalizm'in Düşünsel Temelleri ve Tarihsel Oluşumu," Atatürk Araştırma Merkezi Dergisi, Cilt: 26, Say1: 77, 2010, s.316.

24 Levent Köker, "Kemalizm/Atatürkçülük: Modernleşme, Devlet ve Demokrasi," Modern Türkiye'de Siyasi Düşünce Cilt: 2 Kemalizm, İletişim Yayınları, İstanbul, 2006, s. 97

25 Atilla İlhan, "Kemalizm Müdafaa-i Hukuk Doktrini," Modern Türkiye’de Siyasi Düşünce Cilt: 2 Kemalizm, İletişim Yayınları, İstanbul, 2006, s. 527.

26 Feroz Ahmad, Demokrasi Sürecinde Türkiye 1945-1980, Çev: Ahmet Fehmi, Hil Yayın, İstanbul, 1996, s.114. 
edilmektedir. Levent Köker'in ifadesi ile "her yorum sahibi veya siyasi akım mensubu muhalifini kendi gerçek Kemalizm veya Atatürkçülüğü açısından sahte olmakla” suçlamaktadır. ${ }^{27}$

Atatürk’ün sağlığında iken Atatürkçülüğün farklı yorumları gün yüzüne çıkmıştır. Ancak Atatürkçülüğün farklı yorumlarının ayrıştığı asıl kavşak noktası, Tek Parti döneminin sona erdiği, çok partili hayata geçildiği 1946 yılı olmuştur. İkinci Dünya Savaşı, Türkiye'de siyasi iklimi dondurmuştur. Savaşın hemen bitiminde dünyada iki kutuplu yeni bir düzen kurulur iken Türkiye bu Yeni Dünya' da yerini ve konumunu belirlemeye çalışmıştır. İç ve dış koşulların olgunlaşması ile Cumhurbaşkanı İnönü, 19 Mayıs 1945 tarihli konuşmasında çok partili siyasi hayata geçişe dair önemli adımlar atılabileceğinin işaretini vermiştir. 17 Haziran 1945' de altı milletvekilliği için yapılan ara seçimlerde, ilk kez Tek Parti resmi olarak adayları dikte etmemiş, adaylık ve seçim sürecinin serbest bırakılması Demokrasi yolunda atılan bir adım sayılmıştır. ${ }^{28}$ Siyasi ortamın yumuşaması sayesinde Nuri Demirağ adlı bir sanayici, Temmuz ayının başında Milli Kalkınma Partisi adlı yeni bir siyasi parti kuruluşu için başvurmuş fakat yeni partinin resmi kuruluş izni ancak Eylül ayının son haftasında verilmiştir. ${ }^{29}$ Böylelikle Cumhuriyet tarihinde üçüncü kez çok partili siyasi hayat resmen başlamıştır. Fakat Milli Kalkınma Partisi, Cumhurbaşkanı İsmet İnönü tarafından ciddi bir rakip olarak algılanmamış, İnönü, 1 Kasım 1945'de yaptığ 1 Meclis açılış konuşmasında ciddi bir muhalefet partisine gereksinim duyulduğunu açıkça ifade etmiştir. ${ }^{30}$ İnönü’nün aradığ 1 muhalif parti, çeperden değil siyasi hayatın tam merkezinden Cumhuriyet Halk Partisi'nin içinden doğmuştur. 7 Haziran 1945'de CHP Meclis grubuna demokratik talepler içeren "Dörtlü Takrir'in" verilmesi ile Parti içi muhalefet belirlemeye başlamıştır. Bu takriri imzalayanlar Celal Bayar, Adnan Menderes, Fuat Köprülü ve Refik Koraltan'dır. ${ }^{31}$ Dörtlü takrir sahipleri 7 Ocak 1946 günü Celal Bayar'ın liderliği altında Demokrat Parti'yi kurmuşlardır. Parti kurulmadan daha bir kaç ay öncesine dek dört kurucu Celal Bayar, Adnan Menderes, Fuat Köprülü ve Refik Koraltan CHP üyesi idiler. Yeni partinin başkanı olan Celal Bayar, Atatürk’ün son başbakanıdır ve parti kuruluş sürecinde İnönü ile sürekli ilişki içinde olmuştur. İnönü tarafindan öngörülen çok partili siyasi düzen sınırlı bir açılımdır. Bu sınırlı demokratik aç1lımda sol kanat bulunmamakla birlikte çok partili hayat sağın tüm eğilimlerine de açık değildir. Böylelikle meşru kabul edilen tek muhalefet, iktidardaki tek partiden fazla ayrışmayan yarı-liberal sağ bir muhalefeti temsil eden Demokrat Parti olmuştur. ${ }^{32}$ Demokrat Parti, iktidardan radikal biçimde farklılaşan bir parti değildir. ${ }^{33}$

Demokrat Parti zorlu ve mücadele ile geçen dört yılın ardından 1950 seçimlerinde çoğunluğu elde ederek iktidar olmuştur. Serbest ve dürüst bir seçim sonucu, iktidar 27 yıl sonra değişmiş ve

27 Levent Köker, "Kemalizm/Atatürkçülük: Modernleşme, Devlet ve Demokrasi," Modern Türkiye'de Siyasi Düşünce Cilt: 2 Kemalizm, İletişim Yayınları, İstanbul, 2006, s. 97-98.

28 Cem Eroğul, Demokrat Parti Tarihi ve İdeolojisi, Yordam Kitap, İstanbul, 2019, s.1-7.

29 Cemil Koçak, İkinci Parti Türkiye'de İki Partili Siyasi Sistemin Kuruluş Yılları (1945-1950) Cilt 1, İletişim Yayınları, İstanbul, 2010, s.674-689.

30 Feroz Ahmad, Demokrasi Sürecinde Türkiye 1945-1980, Çev: Ahmet Fehmi, Hil Yayın, İstanbul, 1996, s.26-27.

31 Kemal Karpat, Türk Demokrasi Tarihi, İstanbul Matbaasl, İstanbul, 1967, s. 129.

32 Cem Eroğul, "Çok Partili Düzenin Kuruluşu 1945-1971," Geçiş Sürecinde Türkiye, Belge Yayınları, İstanbul, 1992, s. 115.

33 Tanel Demirel, Türkiye'nin Uzun On Yll Demokrat Parti'nin İktidarl ve 27 Mayls, İstanbul Bilgi Üniversitesi Yayınları, İstanbul, 2016, s. 102. 
Demokrat Parti dönemi başlamıştır. ${ }^{34}$ Tanel Demirel'in ifade ettiği gibi Demokrat Parti'nin sandık zaferi ile Cumhuriyetçi ve modernist paradigma içinde kalınarak farklı patikalar takip edilmesi gerektiğini ifade eden bir çizgi iktidara gelmiştir. ${ }^{35}$ Bu paradigmanın sıfatlarından ve bileşenlerinden birinin Atatürkçülük olduğu muhakkaktır.

27 yıllık tek parti iktidarı ile özdeşleşen, devlet aygıtının içinde büyük bir güce sahip Milli Şef İnönü'nün bu iktidar değişikliğine ne ölçüde uyum sağlayacağı Demokrat Partililere göre belirsizdir. İnönü fobisi olarak nitelendirilebilecek bu korkuyu aşmak için DP, iktidara geldikten sonra siyasi rakibi CHP'yi ve onun lideri İnönü'nün karizmasını yıpratıp sıradan bir muhalefet partisi lideri haline getirmeye çalışmıştır. İnönü’nün karizmasını yok etmek için Atatürk’ü ön plana çıkarmışlardır. ${ }^{36}$ Demokrat Parti, Atatürk dönemini eleştiriden masun tutarken, bütün eleştirileri 1938 sonrasına yöneltme stratejisini uygulamıştır. ${ }^{37}$ Üstelik Demokrat Parti, Atatürk’e bağlılık konusunda yaptığı hamlelerin ertesinde Cumhuriyet Halk Partisi’nin örgütsel bütünlügünü hedef almıştır. 1951 Temmuz ayında Demokrat Parti, "Atatürk Aleyhine İşlenen Suçlar Hakkında Kanunu" çıkarmasından bir ay sonra 8 Ağustos 1951'de Cumhuriyet Halk Partisi'ne ait olan Halkevlerinin devlete iadesi yasası TBMM'de kabul edilmiştir. ${ }^{38} 10$ Kasım 1953 'te Atatürk'ün Naaşı'nın Anıtkabir'e defninden hemen bir ay sonra bu defa Demokrat Parti, Cumhuriyet Halk Partisi'ne en güçlü darbesini indirmiştir. 14 Aralık 1953'te, Cumhuriyet Halk Partisi'nin mallarına el konulmasını ve hazineye devredilmesini kararlaştıran yasa tasarısı kabul edilmiştir. ${ }^{39}$ Bu noktada, Demokrat Parti'nin Atatürk ve Atatürkçülük ile ilgili tutumunun kesinlikle pragmatist, apolojetik (savunmac1-önlemci) olmanın ötesinde olduğunu belirtmek gerekmektedir. Demokrat Parti, Atatürkçülügüun düşünsel ve politik mirasını önemseyen ve sahip çıkan bir zihniyet yapısındadır. 27 Mayı1s60 Askeri Darbesinden sonra geriye dönük kurgulanan şemanın aksine 1946-1960 arası dönemde CHP-DP kutuplaşması Kemalizm/Anti Kemalizm ekseninde şekillenmemiştir. ${ }^{40}$ Gerçekte, başta Celal Bayar olmak üzere birçok Demokrat Partili, Atatürk'e kişi olarak bağlı olmalarının ötesinde Atatürk'ün düşüncelerinin de takipçisi oldukları muhakkaktır. DP, seçim zaferlerini ve çok partili hayatı, İnönü döneminde dondurulduğunu iddia ettikleri inkılâp hareketini yeniden canlandırma hamlesi olarak anlamlandırmıştır. Amaçlarının Atatürkçülüğü, Atatürk’ün sağlığında olduğu gibi canlı bir ideoloji haline getirmek olduğunu iddia etmişlerdir. Demokrat Partili yöneticiler, Tek Partinin yozlaştırdığını ileri sürdükleri Atatürkçülüğü restore ettiklerini düşünmektedirler. ${ }^{41}$ Mustafa Kemal Atatürk, çok partili hayatta da "Kurtarıcı," "Ulu Önder, "

34 Bernard Lewis, Modern Türkiye’nin Doğuşu, Çev: Metin Kıratlı, TTK Basımevi, Ankara, 2007, s. 305311

35 Tanel Demirel, Türkiye’nin Uzun On Yll Demokrat Parti’nin İktidarl ve 27 Mayls, İstanbul Bilgi Üniversitesi Yayınları, İstanbul, 2016, s. 102.

36 Feroz Ahmad, Demokrasi Sürecinde Türkiye 1945-1980, Çev: Ahmet Fehmi, Hil Yayınları, İstanbul, 1996,s.48; Erik Jan Erik Jan Zürcher, Modernleşen Türkiye’nin Tarihi, Çev: Yasemin Saner Gönen, İletişim Yayınları, İstanbul, 2007, s. 323.

37 Tanel Demirel, Türkiye'nin Uzun On Yll Demokrat Parti’nin İktidarl ve 27 Mayls, İstanbul Bilgi Üniversitesi Yayınları, İstanbul, 2016, s. 114.

38 Zafer Gazetesi, 9 Ağustos 1951

39 Ulus Gazetesi, 15 Aralık 1953

40 Tanıl Bora, Yüksel Taşkın, “Sağ Kemalizm,” Modern Türkiye’de Siyasi Düşünce Cilt: 2 Kemalizm, İletişim Yayınları, İstanbul, 2006, s. 529-531.

41 Tanıl Bora, “Celal Bayar,' Modern Türkiye’de Siyasi Düşünce Cilt: 2 Kemalizm, İletişim Yayınları, İstanbul, 2006, s. 549-551: Feroz Ahmad, Demokrasi Sürecinde Türkiye 1945-1980, Çev: Ahmet Fethi, 
"Кигиси" ve Cumhuriyetin ideallerini, felsefesini, yaşam tarzını temsil eden bir sembol olmayı sürdürmüş ancak bu kez partiler üstü bir konuma yükselmiştir. ${ }^{42}$

İki Partili hayat sınırlı bir açılım olsa da elbette Demokrat Parti ve Cumhuriyet Halk Partisi arasında siyasal düşünce, tutum farklılıkları olduğu gibi Atatürkçülüğü yorumlamada da farklılar vardır. İki partili hayat en azından başlangıçta Atatürk döneminin iki siyasi aktörünün İnönüBayar'ın arasındaki rekabetin kurumsallaştırılmasıdır. İki siyasi figürün arasındaki rekabette farklılaşan görüşler, devletin ekonomiye müdahalesi ve ekonomide planlanmaya dairdir. Bayar'a ve elbette Demokrat Parti'ye göre, ekonomiye devletin müdahalesi ve ekonomide planlamaya karar verilmesi 1930'lu yılların şartları içine yapılması gerekli geçici bir uygulamadır. Özel girişimci sinıf yeteri derecede geliştiğinde devlet girişimleri özelleştirilecek ve serbest piyasa ekonomisi kurulacaktır. Üstelik Demokrat Partililer, yapmaya çalıştıkları bu dönüşümü, Atatürkçülüğün esas amaçlarına bağlı kalmak olarak görmüşlerdir. ${ }^{43}$ Modernleşme ve ulus-devlet projesinde milli burjuvazi yaratmak için uygulanan liberal popülist politikaları ile Demokrat Parti Atatürkçülüğün merkez-sağ yorumunun temsilcisine dönüşmüştür. Atatürk’ün son Başbakanı olan Celal Bayar, Atatürkçülüğün merkez-sağ politik söyleme uyarlanması bakımından kurucu önem taşımaktadır. ${ }^{44}$ Bayar, kendini Atatürk'ün en yakını olarak takdim etmiş, “Atatürk'ün kendi kucağında öldüğünü ve sana itimat ederim evladım" dediğini birkaç kez anlatmıştır. ${ }^{45}$ Dönemin basınında, Bayar'a milletin Atatürk'ün en çok itimat ettiği adam olduğu için güvendiği yazılmış hatta Bayar, Atatürk'ün "yakın akrabası" olarak bile takdim edilmiştir. ${ }^{46}$ Celal Bayar, demokratikleşmeyi "İnkılâbı ve Atatürk'ün eserini tamamlamakla" "Büyük halaskarın açtığı yolda yürümek" ile meşrulaştırmıştır. Yine Bayar'a göre, kişisel hak ve özgürlükler, Atatürk'ün başlattığ 1 kurtuluş ve milli egemenliğin tamamlanması anlamına gelmektedir. ${ }^{47}$ Demokrat Parti iktidarı, Atatürk'ün hedeflediği milli hâkimiyetin kendi iktidarlarında gerçekleştiğine böylelikle Türk inkılâbının hedeflerinden birinin gerçekleştiğini düşünmektedir. Atatürk döneminde haklı sebeplerle gerçekleşemeyen demokrasi adlı siyasi ideali, “İnönü’nün intikal devrini” kapatan Demokrat Parti gerçekleşmiştir. ${ }^{48}$

Adnan Menderes, Demokrat Parti'nin ilk hükümet programında inkılâpları “millete mal olmuş inkılâplar ve millete mal olmamış inkılâplar" olarak ayırmıştır. Menderes' in hükümet programında Atatürk'ün inkılâpları arasında yaptığı ayrıma bir açıklık getirilmemiştir. ${ }^{49} 13$ Haziran 1950'de DP

Hil Yayını, İstanbul, 1996, s.54.

42 Hasan Ünder, “Atatürk İmgesinin Siyasal Yaşamdaki Rolü,” Modern Türkiye'de Siyasi Düşünce Cilt: 2 Kemalizm, İletişim Yayınları, İstanbul, 2006, s. 153.

43 Feroz Ahmad, Demokrasi Sürecinde Türkiye 1945-1980, Çev: Ahmet Fehmi, Hil Yayınları, İstanbul, 1996,s.54.

44 Tanıl Bora, Yüksel Taşkın, "Sağ Kemalizm,” Modern Türkiye’de Siyasi Düşünce Cilt: 2 Kemalizm, İletişim Yayınları, İstanbul, 2006, s. 531.

45 Tanıl Bora, “Celal Bayar,” Türkiye'nin 1950'li Ylllarl, Editör: Mete Kaan Kaynar, İletişim Yayınları, İstanbul, 2016, s.154

46 Ali Naci Karacan, “Atatürk'ün Ruhu,” Milliyet Gazetesi, 8 Haziran 1950, s.1,5

47 Tanıl Bora, “Celal Bayar," Türkiye'nin 1950'li Ylllarl, Editör: Mete Kaan Kaynar, İletişim Yayınları, İstanbul, 2016, s.154

48 Tanel Demirel, Türkiye'nin Uzun On Yll Demokrat Parti'nin İktidarl ve 27 Mayls, İstanbul Bilgi Üniversitesi Yayınları, İstanbul, 2016, s. 113.

49 Anıl Varel, “Ellili Yıllarda Muhalefet: Hükümete Yönelik Temel Eleştirler ve DP Karşısında CHP’nin İdeolojik Konumlanışı," Türkiye’nin 1950'li Yılları, Editör: Mete Kaan Kaynar, İletişim Yayınları, İstanbul, 2016, s. 221. 
grubunda Adnan Menderes, "Millete mal olmamış, milletin vicdanına bir değirmen taşı ağırlığı ile çökmüş olan bazı tedbirleri ortadan kaldıracağız" vaadinin ardından Türkçe ezan uygulaması kaldırılmıştır. ${ }^{50}$ Demokrat Parti, İstanbul ve Ankara radyolarında, her pazartesi, çarşamba ve cuma günleri tanınmış hafızlar tarafından Kur'an okunması uygulamasını başlatmış, ilkokulların 3, 4 ve 5. sınıflarına din dersi konulmuştur. ${ }^{51}$ Demokrat Parti döneminde millete mal olmamış inkılâplar hususunda en önemli adım, CHP'nin desteği ile Arapça ezan yasağının kaldırılması olmuştur. İnkılâplar ile ilgili daha az dikkat çekici bir hamle, dilde sadeleşmeye yöneliktir. 1945 yılında sadeleştirilen Anayasa'nın dili, 1952'de değiştirilerek eski metin kabul edilmiştir. ${ }^{52}$ Ancak bu değişim, Anayasa'nın teknik metni ile sınırlı kalmamış, basında, sinema sektöründe gündelik hayatta dil inkılâbından önceki lisana ve kelimelere dönüş desteklenmiştir. Demokrat Parti, Cumhuriyetin inkılâplarını tersine çeviren bir karşı-devrim hareketi olmadığı gibi halk adına hareket ettiğini iddia eden tek parti popülizminin devamı da değildir. DP, özel teşebbüsü öne çıkaran, halkın taleplerini dikkate alan kapsayıcı bir popülist siyasal harekettir. ${ }^{53}$ Zaten, halkın taleplerine yönelmek ve onların desteğini kazanmak için uygun söylemler geliştirmek demokrasilerde siyasi partilerin varoluş sebebidir.

Demokrat Parti, yerel eşrafa ve mülk sahibi orta sınıflara dayanan, jakoben modernizme karşı tedrici bir modernleşmeden yana olan muhafazakar-liberal bir geleneği temsil eder. ${ }^{54}$ MerkezSağ Atatürkçü yorumda, modernleşme, ilerleme denilince muasır medeniyetin görünür somut veçheleri üretim artı̧̧, elektrik, su, yollar, barajlar, köprüler, imar ve inşa faaliyetleri anlaşılır. Atatürkçülüğün sanat, edebiyat, yaşam tarzı, giyim kuşam, kadın-erkek ilişkileri gibi alanlarda değişime öncelik veren kültürel modernleşme vurgusu reddedilmemekle birlikte ikinci plana itilir. ${ }^{55}$ Demokrat Parti'ye göre, Atatürk'ün göstermiş olduğu muasır medeniyet seviyesine iktisadi kalkınma ile ulaşılacaktır. Demokrat Parti'nin modernizm perspektifi, modernleşmenin dinamiğini ve güvencesini Atatürkçü kültürel inkılâplarda değil iktisadi değişimde arar. Bu çerçevede gerçek modernleşme ancak kalkınma ve refah artışı gerçekleşecektir. ${ }^{56}$ Merkez-Sağ Atatürkçülük yorumunun en belirgin ve en güçlü vurgusu, muasır medeniyet seviyesine ulaşma şiarı olmuştur.

Demokrat Parti, Atatürkçülüğün çok partili sisteme uyarlanmasında ve partiler arasında siyasi kutuplaşma ortamında yeniden üretilmesinde önemli bir rol oynamıştır. ${ }^{57}$ Başbakan Adnan Menderes'in “Atatürk'ün ne Halk Partisi'nin ne de Demokrat Parti'nin ya da herhangi bir kimsenin

50 Tanıl Bora, “Adnan Menderes” Türkiye’nin 1950'li Yllları, Editör: Mete Kaan Kaynar, İletişim Yayınları, İstanbul, 2016, s. 345.

51 Hüseyin Şeyhanlığlu, "Demokrat Parti Döneminde Türkiye'de Kültürel Faaliyetler (1946-1960)," Tarih ve Gelecek Dergisi, Cilt 6, Say1 4, Aralık 2020, s.1377.

52 Cem Eroğul, “Çok Partili Düzenin Kuruluşu 1945-1971,” Geçiş Sürecinde Türkiye, Belge Yayınları, İstanbul, 1992, s. 122.

53 Tanel Demirel, Türkiye'nin Uzun On Yll Demokrat Parti'nin İktidarl ve 27 Mayls, İstanbul Bilgi Üniversitesi Yayınları, İstanbul, 2016, s. 127-129.

54 Tanıl Bora, “Adnan Menderes” Türkiye’nin 1950'li Yılları, Editör: Mete Kaan Kaynar, İletişim Yayınları, İstanbul, 2016, s. 333.

55 Tanel Demirel, Türkiye'nin Uzun On Yll Demokrat Parti'nin İktidarl ve 27 Mayls, İstanbul Bilgi Üniversitesi Yayınları, İstanbul, 2016, s. 119.

56 Tanıl Bora, “Adnan Menderes” Türkiye’nin 1950'li Yllları, Editör: Mete Kaan Kaynar, İletişim Yayınları, İstanbul, 2016, s. 342.

57 Tanıl Bora, Yüksel Taşkın, “Sağ Kemalizm,” Modern Türkiye’de Siyasi Düşünce Cilt: 2 Kemalizm, İletişim Yayınları, İstanbul, 2006, s. 531. 
veya zümrenin malı olmadı̆̆g " 58 yönündeki açıklamas1, Demokrat Parti'nin Atatürk'ü partiler üstü bir simgeye dönüştürme çabasının ifadesidir. Demokrat Parti’nin, bu yöntemi Atatürk'ü gündelik siyasal tartışmaların üzerine taşımış ve Atatürk'ü her kesimin siyasi meşruiyet ve referans aracı olarak sunmasını kolaylaştırmıştır.

\section{İnkılapsız Atatürk Filmi: Demokrat Parti’nin “Atatürk Sevgisi”}

“Atatürk Sevgisi” filmi, Atatürk’ün hayatına odaklanan bir yapımdır. Bu yönü ile Atatürk'ün sağlığında çekilen az sayıdaki belgeselden ayrılmaktadır. Atatürk’ün yaşam öyküsünü anlatma iddiası filme "ilk” olma özelliğini kazandırır. 1954 yapımı filmi, Münir Hayri Egeli hazırlamıştır. Fransa'da eğitim alan Münir Hayri Egeli, Cumhuriyetin ilk yıllarından itibaren sanat ve basın dünyasının içinde yer almıştır. Eğitimci-öğretmen olan Egeli, iktidar ile yakınlık kurmak maksadı ile sanatın neredeyse bütün dallarında kendini göstermeye çalışmış, tartışmalı olsa da ürünler vermiştir. Kimi zaman, heykel ve büstler yapmış, kimi zaman tiyatroda görev almış, çocuk hikâyeleri, piyesler yazmış, opera metinleri kaleme almıştır. İran Şahı'nın ziyareti sırasında sergilenen "Özsoy” operasının librettosunu yazmıştır. Renkli ve ilginç bir kişilik olan Egeli, sinema sahasında da çalışmıştır. Halkevinde Kenan Erginsoy ile çektiği kısa filmin ardından 1938'de yönetmenliğini yaptığ uzun metraj “Doğan Çavuş” yarım kalmıştır. 1940’lı yıllarda Yardım Sevenler Cemiyeti, Şeker Sanayi ${ }^{59}$ için kısa tanıtım filmleri çekmiştir. Büyük bir çoğunluğu 1950’li yılların başında tarihi film furyasında çekilen 7 filmin yönetmenliğini yapmıştır. Kısacası, Münir Hayri Egeli, yetişmiş insan gücünün az olduğu cumhuriyetin ilk yılarında hevesi ve hırsı ile sanat ve basın dünyasında sivrilmiş bir şahsiyettir. ${ }^{60}$ Filmin giriş jeneriğine göre, filmin tarih danışmanlığını Özel Şahingiray, müzik arajmanını Asım Güzey, müzik kayıtları Lale Film Stüdyosunda alınan filmin seslendirmesini Esat Toroğlu yapmıştır. Ancak filmde kadın seslendirmen bulunmasına karşın adı jenerikte yer almamaktadır. Filmin kurgusu Almanya Remgen şehrinde bulunan İnternationale FilmUnion A.G. şirketinde Anny Lautenbacher ve Rolf Trurthmann tarafindan yapılmıştır. "Atatürk Sevgisi” filminin finansmanını İş Bankası sağlamıştır. Zaten 44 dakika 56 saniye ${ }^{61}$ süreli filmin giriş jeneriğinin başında "Büyük kurucusunun aziz hatırasına Türkiye İ̧s Bankası A.Ş. bu küçük eseri takdim etmekle şeref ve bahtiyarlık duyar" cümlesi yer alır. "Atatürk Sevgisi," Türkiye'de bir bankanın finansmanını sağladığ 1 ilk yapımlardan biridir. 1953 yılında Denizbank da renkli bir dokümanter olan İstanbul'u tanıtan "Bir Şehrin Hikayesi” filmine sponsor olmuştur. ${ }^{62}$ Her iki filmi de başarısız projeler olarak niteleyen Burhan Arpad, film sanayine bankacılık sektörünün yatırım girişimlerinin "bir takım kombinezonlar" ile başarısızlığa uğratıldığını yazmaktadır. Ayrıca Arpad, İş Bankasının “Atatürk Sevgisi” deneyiminden sonra yeni bir filme yatırım yapmayacağını tahmininde bulunmuştur. ${ }^{63}$ Burhan Arpad, tahmininde yanılmamış, bankacılık sektörü sinemaya uzun bir süre yatırım yapmamıştır. Ancak Bankacılık sektörünün film yatırımları ekonomik, rasyonel gerekçelerden ziyade siyasi yönlendirmeler ile gerçekleşmiştir. İş Bankasının ilk Müdürü

\footnotetext{
58 Milliyet Gazetesi, 21 Kasım 1953

59 Süleyman Beyoğlu, İmparatorluktan Cumhuriyete Türk Sineması (1895-1939), Dergâh Yayınları, İstanbul, 2018,s. 120.

60 Münir Hayri Egeli’nin detaylı biyografisi için bkz. Tunç Boran, “Türk Sinema Tarihinden İlgi Çekici Bir İddianın İncelenmesi,” Türk Sinema Tarihine Farklı Bakışlar, Detay Yayıncılık, Ankara, 2020,s.4-22.

61 Kültür ve Turizm Bakanlığı Sinema Genel Müdürlüğü arşivinde yer alan kopyanın süresidir.

62 Cumhuriyet Gazetesi, 19 Şubat 1954 s.2

63 Burhan Arpad, "Atatürk Sevgisi” Sinema Tenkitleri, Vatan Gazetesi, 1 Mayıs 1954, s.4.
} 
ve dönemin Cumhurbaşkanı Celal Bayar'ın filmin finansmanında ve gerçekleşmesinde etkin olduğu şüphesizdir.

Atatürkhakkındabirbelgesel film projesinin ilhamkaynağıbilinmemeklebirlikteCelal Bayar'1 1954 yılı başında ABD'ye yaptığı ziyarette izlediği Atatürk filmi etkilemiş olması muhtemeldir. Gazete haberine göre, 26 Şubat 1954 günü New York'ta Julien Bryan'1n “Reborn Turkey” filmini izleyen Bayar, duygulanmış ve gözleri yaşarmıştır. ${ }^{64}$ Filmin yapım sürecine bakıldığında hızlı bir karar alındığı ve kısa bir sürede filmin hazırlandığı düşünülmektedir. 1954 yılının Nisan ayı başlarında gazetelerde çıkan bir haberde, Atatürk'ü eserleri ile canlandıran ve inkılâpları belirten bir filmin hazırlanması için yapılan çalışmaların süratle devam ettiği yazmaktadır. Haberde, çeşitli kurumlarda ve İnkılâp Tarihi Enstitüsü'nde dağınık bir halde bulunan Atatürk filmlerinin toplandığ 1 bilgisi verilmiştir. Filmi hazırlayan komitenin Atatürk'ün doğduğu eve ait kısımları çekmek için Yunanistan'a hareket ettiği ve filmin Almanya'da tamamlanacağı ifade edilmiştir. Ayrıca haberde, filmin 23 Nisan'a kadar yetiştirilmesi için çalışıldığ 1 duyurulmaktadır. ${ }^{65}$ Haberde adı açıklanmayan film, "Atatürk Sevgisi" filmidir. Haberde, filmin 23 Nisan Ulusal Egemenlik ve Çocuk Bayramı'na yetiştirilmesine çalışıldığından söz edilse de film, müellifleri tarafından daha önemli görülen bir tarihe yetiştirilmeye çalışılmıştır. "Atatürk Sevgisi” fillmi, 2 Mayıs 1954 tarihinde yapılacak Milletvekili Genel Seçimlerine bir hafta kala sinemalarda gösterilmiştir.

"Atatürk Sevgisi” filminin gerçekleşmesinin ardındaki irade kuşkusuz dönemin iktidarı Demokrat Parti'dir. Ancak filmin adını Atatürk Sevgisi olarak belirleyen filmin yönetmeni Münir Hayri Egeli’dir. 1947 yılında, Cemal Kutay’ın Millet Dergisi’nde Münir Hayri Egeli’nin yönetmenliğinde "Atatürk Sevgisi" adlı kurmaca film çekileceğini kamuoyuna duyurulmuştur. Büyük bir kampanya eşliğinde sunulan “Atatürk Sevgisi” film projesine, CHP iktidarı döneminde Sansür Heyetinden izin çıkmamıştır. ${ }^{66}$ Egeli, 1947' de kurmaca film olarak sunduğu filmin ismini 1954 yılında bu defa arşiv görüntülerinden oluşan bir belgesele vermiştir.

“Atatürk Sevgisi” filminin giriş jeneriği, kitap sayfalarının açılması şeklinde yapılmıştır. 1940’lı yıllarda oldukça popüler olan kitap açılması biçiminde giriş jeneriğinin en ünlü örnekleri Walter Lang'ın yönettiği “The Blue Bird” (1940) ve özellikle Frank Capra'nın “It's a Wonderful Life” (1946) filmleridir. Egeli, giriş jeneriğinde bu popüler biçimi, 1 Mart 1954'te gösterime giren yönetmenliğini yaptığı "Nilgün” filminde de uygulamıştır. Egeli, giriş jeneriğinde yaratıcılığın sınırlarını pek zorlamamıştır. Giriş jeneriğinin öncesinde filmin "Atatürk'ün bütün hayatını nakletmek iddiasında olmadı̆̆ ancak özel ve resmi arşivlerden toplanan bir hatıralar mecmuası" olduğu yazılmıştır. Bu not ile filme gelmesi muhtemel eleştirilerin önü alınmak istenmiştir. Giriş jeneriğinin ardından yine bir not ile film açılır. Bu defa el yazısı ile yazılı not, erkek seslendirmen tarafından okunur. Yazının altında veya ses kuşağında notta yazılı cümlelerin Atatürk'e ait olduğuna dair ifade yer almasa da notun veriliş biçimi Atatürk'e ait bir vecize olduğunu gösterir. Söz konusu yazı şu şekildedir:

"Bir gün gelebilir biz unutuluruz. Bizi inkâr edenler hatta bizi taan edenler de bulunabilir. Ektiğimiz tohumlar o kadar canlıdır ki fikirlerimiz Hint'ten, Çin'den, Mısır'dan döner dolaşır

64 Cumhuriyet Gazetesi, 27 Şubat 1954, s.1-6.

65 Milliyet Gazetesi, 8 Nisan 1954, s.7.

66 Tunç Boran, "Türk Sinema Tarihinden İlgi Çekici Bir İddianın İncelenmesi," Türk Sinema Tarihine Farklı Bakışlar, Detay Yayıncılık, Ankara, 2020, s..22-25. 


\section{feyizli meyveleri inanan kalpleri doyurur."}

Atatürk'ten alıntı iddiası taşıyan sözler, Demokrat Partililerin İnönü döneminde Atatürk'ün unutturulmaya çalışıldığı iddiasını destekler niteliktedir. Atatürk'ü inkâr ve taan edenler elbette İnönü'nün CHP'sidir. Demokrat Parti ile de Atatürk'ün fikirleri yeniden gündeme gelmiştir. DP'liler için Atatürk'ün bu sözleri kehanet olarak görülebilir ancak bu vecize Münir Hayri Egeli dışında hiçbir kaynakta geçmemektedir. Üstelik bu vecize, ilk defa "Atatürk Sevgisi" filminde ortaya çıar. Bu vecize, film ile aynı yıl basılan Münir Hayri Egeli'nin "Bilinmeyen Yönleriyle Atatürk" kitabında da yer almaktadır. Kitapta, bu vecizenin Atatürk'e ait olduğu belirtilmektedir. Üstelik 1937 tarihinde "Bir İnkılâp Çocuğuyum" adlı film senaryosunun altına Atatürk'ün kendi el yazısı ile yazdığı iddia edilmektedir. Oysa söz konusu senaryonun var olduğu dahi şüphelidir. ${ }^{67}$ Kaynak açısından şaibeli ve zayıf olan vecizenin kitap ve film versiyonu arasında farklılar bulunmaktadır:

"Bir zamanlar gelir, beni unutmak veya unutturmak isteyen gayretler belirebilir. Fikirlerimi inkâr edenler ve bana taan edenler çıkabilir. Hatta bunlar benim yakın bildiğim ve inandıkların arasından bile olabilir. Fakat ektiğimiz tohumlar o kadar özlü ve kuvvetlidirler ki bu fikirler, Hint'ten, Misır'dan döner dolaşır gene gelir, feyizli neticeleri kalpleri doldurur. " ${ }_{68}$

Vecizenin iki farklı versiyonunda anlam bakımından ciddi fark olmasa da kitapta bir cümle eklendiği dikkat çekmektedir. "Hatta bunlar benim yakın bildiğim ve inandıkların arasından bile olabilir" cümlesi ile İnönü'ye yönelik ima güçlendirilmiştir. Münir Hayri Egeli'nin tek kaynak olduğu diğer Atatürk sözlerinde de benzer şekilde farklı versiyonlar bulmak mümkündür. Münir Hayri Egeli'nin kaynaklık ettiği Atatürk'ün sinema ait vecizede de iki farklı versiyon vardır. Sinemanın önemi üstüne Atatürk'e dayandırılan sözlerdeki farklılıklara işaret eden Âlim Şerif Onaran'a göre, sinemaya dair sözün ardında Atatürk öldükten sonra onun adına sloganlar üretmiş olduğu bilinen Münir Hayri Egeli'nin gayretkeşliği yatmaktadır. ${ }^{69}$ Atatürk adına sözler ve sloganlar üretmesi ile meşhur Münir Hayri Egeli güvenilir bir kaynak olmaktan çok uzaktır. Söz konusu kitapta ve filmin başında yer alan ve başka hiçbir kaynakta yer almayan Atatürk'e dayandırılan vecizeye şüphe ile yaklaşılmalıdır. Atatürk'e bağl1lık üzerinden dönemin siyasi partileri arasında yaşanan rekabette bu vecize, Demokrat Parti'nin görüşlerine ve suçlamalarına Atatürk'ü referans gösterme firsatı sunmuştur.

Tarihi olgulara dayanması gereken belgesel, gerçekliği “şüpheli” bir vecize ile başlamaktadır. Bu el yazısı notun ardından film, Selanik görüntüleriile açılır. Film, genel olarak arşiv görüntülerinden oluşmaktadır. Yalnızca Selanik görüntüleri, film ekibi tarafından çekilen aktüel görüntülerdir. Kısa bir sunumdan sonra Atatürk'ün kendi çocukluğuna dair gazetecilere anlattı̆̆ anekdot verilir. $^{70}$ Anne-babası arasında yaşanan geleneksel-modern okul tartışması, babasının ölümü ve dayısının yanında tarlada karga kovalama anısı birinci tekil şahıs olarak anlatılır. Atatürk çocukluğuna dair anıları, sıradan bir şekilde tasvir eder. Ancak belgeselin müellifinin yazdığı giriş metninde tam tersi “insanüstü" bir sunum vardır. Atatürk'ün doğumunu Selanik şehrinin tarihinin en "büyük"

67 Konu hakkında detaylı bir araştırma için Bkz. Tunç Boran, “Türk Sinema Tarihinden İlgi Çekici Bir İddianın İncelenmesi,” Türk Sinema Tarihine Farklı Baklşlar, Detay Yayıncılık, Ankara, 2020

68 Münir Hayri Egeli, Bilinmeyen Yönleriyle Atatürk, Berikan Yayınevi, Ankara, 2004, s.6,128.

69 Âlim Şerif Onaran, Türk Sineması (Cilt 1), Kitle Yayınları, İstanbul, 1994, s.102.

70 Atatürk, çocukluğuna dair anlattığı hatıra, ilk defa 1922 yılında Vakit gazetesinde yayınlanır. Bkz. Ahmet Emin Yalman, Yakın Tarihte Gördüklerim, Geçirdiklerim Cilt 1, Pera Turizm ve Ticaret A.Ş, 1997,.s. 698-721, 
günü sayan belgesel, Atatürk'ün orada doğmasını şehrin "büyük talihi” olarak adlandırmaktadır. Ayrıca bu giriş metninde ciddi bir hata vardır. Belgeselin metninde, Atatürk'ün babası "münevver bir asker" olarak tanıtılmaktadır. Ancak yalnızca bir dakika sonra Atatürk'ün birinci tekil şahıs aktarılan hatıratında babasının rüsumatta (gümrük) memur olduğu aktarılır. Atatürk'ün babasının mesleğine dair çelişki-hata filmin gelişigüzel, ciddiyetsiz ve özensiz hazırlandığını gösterir.

“Atatürk Sevgisi," Selanik görüntüleri gibi kısa süreli aktüel çekimlerin dışında arşiv görüntülerinden hazırlanmıştır. Ancak film, arşiv görüntülerinden derleme bir fillm olmaktan öte bir kolâja benzemektedir. Çeşitli arşivlerden ve belgesellerden alınan nutuklar bir nedensellik bağ1 oluşturulmadan birbiri arkasına sıralanmıştır. Filmde, Atatürk'ün 1932 senesinde Türkiye Büyük Millet Meclisi konuşması ${ }^{71}$ kesintisiz bir biçimde 6 dakika olarak verilmiştir. $\mathrm{Bu}$ konuşmanın hemen ardından Cumhuriyetin 10. Yılındaki Atatürk'ün Nutkundan yedi dakikalık bölüm “Türkiye'nin Kalbi Ankara” filminden aynen alınmıştır. Ayrıca Celal Bayar'ın Atatürk'ün naaşının Anıtkabir'e nakil töreninde yaptığı konuşma da kesintisiz 5 dakika verilmiştir. Filmde 18 dakikalık süre Atatürk'ün ve Bayar'ın nutuklara ayrılmıştır. "Atatürk Sevgisi” filmi vizyonda iken tek eleştiri yazısını yazan Burhan Arpad da filmi, "yamalı bohçaya" benzetmektedir. "Atatürk Sevgisi”" filmini, "İstiklal," "Türkiye'nin Kalbi Ankara," Atatürk'ün cenaze töreni ve Anıtkabir'e nakil töreni gibi filmlerin bir halitasl ${ }^{72}$ olarak değerlendiren Arpad filmde, Atatürk'ün ve Bayar'ın nutuklarının başından sonuna kadar dinletilmesini eleştirmektedir. ${ }^{73}$ Nijat Özön, 1957 yılında Adnan Ufuk müstear adıyla yazdığı yazıda, "Atatürk Sevgisi 'ni" film parçalarının uç uca yapıştırılması olarak görmektedir. ${ }^{74}$ Filmde kullanılan arşiv görüntüleri arasında kamuoyunun az bildiği "Gaziantep Savunması" filminden sahneler de vardır. 1935 senesinde Ordu Foto Film Merkezi tarafından çekilen "Gaziantep Savunması" Milli Mücadele döneminde Gaziantep halkının düşmana direnişini canlandırma sahneler ile anlatmaktadır. ${ }^{75} \mathrm{Bu}$ filmden alınan halkın düşmana karşı kitlesel ayaklanma görüntülerini Burhan Arpad, filmin en ilgi çekici sahneleri olarak değerlendirmiştir. ${ }^{76}$ Ancak "Atatürk Sevgisi” filmi, titiz bir arşiv araştırmasının ürünü olarak görünmemektedir. Belli bir tema çerçevesinde arşiv görüntülerinden seçme yapılarak derlemeden öte birbirinden farklı arşiv görüntülerinden büyük parçaların belirli tema olmaksızın gelişigüzel birleştirilmesi ile oluşturulmuştur. Yine de "Atatürk Sevgisi" filminin anlatısında belirli bir kaygı da mevcuttur. Filmde, Demokrat Parti'nin Atatürk'ün gerçek varisi ve takipçisinin Celal Bayar olduğu iddiası belirgin bir şekilde tekrar edilmektedir. Filmde, Atatürk'ten sonra en çok görünen kişi Cumhurbaşkanı Celal Bayar'dır. Filmde, Bayar'dan "Atatürk'ün dostu ve inandiğı Başvekil" ve "Atatürk'ün halefi, talebesi, sadık ve vefakâr arkadaşı" olarak söz edilir. Nijat Özön'e göre; "Atatürk Sevgisi'nin" as1 amac1, Celal Bayar'1 kastederek "iktidardaki birinin ısrarla öne sürülmesidir. ” Özön, Atatürk'ün en yakın çalışma arkadaşını olarak tanımladığı İnönü’nün filmde hiç gösterilmediğini yazmaktadır. ${ }^{77}$ Ancak İnönü uzaktan ve kalabalık içinde dahi olsa birkaç kez çerçeveye girer. Yine de Atatürk döneminde 14 yıl Başbakanlık yapmış olan İnönü'yü filmde

71 Konuşma metni: TBMM Zabıt Ceridesi, Devre 4, İçtima 2, 1 Kasım 1932, Cilt:10, s.3.

72 Halita: Birden çok öğeden oluşmuş karmaşık bir bütün, karışım.

73 Burhan Arpad, "Atatürk Sevgisi” Sinema Tenkitleri, Vatan Gazetesi, 1 Mayıs 1954, s.4.

74 Adnan Ufuk, "Uyuyan Sinema," Yeditepe Gazetesi, Say1:123, 15 Ocak 1957, s:1-6.

75 Cumhuriyet Gazetesi, 11 Aralık 1935, s.6.

76 Burhan Arpad, "Atatürk Sevgisi” Sinema Tenkitleri, Vatan Gazetesi, 1 Mayis 1954, s.4.

77 Nijat Özön, Türk Sineması Tarihi 1896-1960, Artist Yayınları, İstanbul,1962, s.236. 
göstermemek için çaba harcandığı hissedilmektedir. Demokrat Parti'nin muhalifi Akis dergisinde "Atatürk Sevgisi" filminin Demokrat Parti'nin Atatürk'ün hakikî siyasî vârisinin Celâl Bayar olduğu iddiasını tekrarladığı yazılmıştır. ${ }^{78}$ Burhan Arpad da "Atatürk Sevgisi" filminin temel endişesinin Atatürk'ün hayatını anlatmak olmadığını, asıl maksadının "Atatürk ve Bayar'ın Türk inkılâp hareketindeki müşterek rollerini belirtilmek arzusu" olduğunu iddia etmektedir. Bu amacı yüzünden Arpad'a göre, belgesel tarihi gerçeklere sadakat göstermemektedir. ${ }^{79}$ "Atatürk Sevgisi," gerek içerik yönünden gerekse de sinemalarda gösterime girme tarihi sebebi ile propaganda filmi olarak itham edilmektedir. Film, 24 Nisan 1954 Cuma günü Milletvekili Genel Seçimlere bir hafta kala sinemalarda gösterime girmiştir. "Atatürk Sevgisi" filmi, gazete ilanlarında "senenin en müstesna değerli dokümanter filmi" olarak takdim edilmiştir. İlanlarda ayrıca filmde, "Büyük Ata'nın hayatından alınmış ve şimdiye kadar hiç bir yerde görmediğiniz eşsiz vesikalar, O'nun hususi hayatına ait fevkalâde parçalar, O'nun inkılâp fikirleri etrafında toplanmış çok güzel bir eser, Atatürk'ü hayatının muhtelif safhalarında doya doya göreceğiniz harikulade bir film" gibi övgüler yer almaktadır. ${ }^{80}$ Film, Ankara'da Park, Sus ve Ankara sinemalarında seçim gününe kadar bir hafta gösterimde kalmıştır. ${ }^{81}$ Park ve Sus sinemaları İş Bankası iştiraki salonlardır. ${ }^{82}$ Film, diğer şehirlerde de gösterilmiştir. Filmin gişe başarısı ve hâsılatı hakkında Burhan Arpad'ın kişisel gözlemi dışında bir bilgi bulunmamaktadır. Arpad, filmin gösteriminin dördüncü akşamı bin iki yüz kişilik salonda yüz seyircinin olmadığını yazmaktadır. ${ }^{83}$ "Atatürk Sevgisi" filmi, genel olarak bir propaganda filmi olarak değerlendirilmişsir. "Türkiye'de Toplumsal Değişme ve Belgesel Sinema" adlı çalışmasında belgesel sinema tarihini dönemleştiren Hakan Aytekin'e göre, "Atatürk Sevgisi" Propaganda döneminin ürünü olan belgesel görünümünde hazırlanan bir filmdir. ${ }^{84}$ Nijat Özön de seçimlerden evvel gösterime giren filmi, Demokrat Parti'nin propagandası olarak değerlendirmektedir. Özön'e göre "gelişigüzel bir araya getirilen” Atatürk Sevgisi filminde Atatürk'e ait zengin arşiv malzemesi sorumsuz ellerde harcanmıştır. ${ }^{85}$ Erman Şener, "Atatürk Sevgisi" filmine dair yaptı̆̆ değerlendirmede filmin konuya herhangi bir yenilik getirmediğini söylemek ile yetinmiştir. ${ }^{86}$ Film ile ilgili eleştiri yazısında Burhan Arpad, "Atatürk Sevgisinin propaganda uğruna harcandığını," ancak halkın filme ilgi gösteremeyerek gereken cevabı verdiğini yazmaktadır. ${ }^{87}$ Akis dergisine göre de "Atatürk'e ait bir çalışma iddiası ile seçimlerin arifesinde şehir şehir dolaştırılan” fillmin özellikle son bölümünde açıktan açığa Demokrat iktidarın propagandası yapılmıştır. ${ }^{88}$ Filme yönelik eleştiriler, filmin Celal Bayar'ı öne çıkartması ve Demokrat Parti'nin siyasi propagandasını yapmasına odaklanmaktadır. Film, hakikaten Celal Bayar'ı Atatürk'ün yakın

78 “Kendi aramızda,” Akis Dergisi, Sayı:26, 6 Kasım 1954, s.3.

79 Burhan Arpad, "Atatürk Sevgisi” Sinema Tenkitleri, Vatan Gazetesi, 1 May1s 1954, s.4.

80 Yeni Ulus Gazetesi, 24 Nisan 1954, s.6

81 Yeni Ulus Gazetesi, 24 Nisan 1954, s.6; Yeni Ulus Gazetesi, 26 Nisan 1954, s.6; Yeni Ulus Gazetesi, 27 Nisan 1954, s.5; Yeni Ulus Gazetesi, 29 Nisan 1954, s.6; Yeni Ulus Gazetesi, 30 Nisan 1954, s.5; Yeni Ulus Gazetesi, 1 Mayıs 1954, s.3: Yeni Ulus Gazetesi, 2 Mayıs 1954, s.5.

82 İnal Karagözoğlu, Ankara'da Sinemalar Vardı, Bileşim Yayınları, İstanbul, 2004, s.138-140.

83 Burhan Arpad, "Atatürk Sevgisi” Sinema Tenkitleri, Vatan Gazetesi, 1 May1s 1954, s.4.

84 Hakan Aytekin, Türkiye’de Toplumsal Değişme ve Belgesel Sinema, BSB Yayınları, İstanbul, 2017, s.9091.

85 Nijat Özön, Türk Sineması Tarihi 1896-1960, Artist Yayınları, İstanbul,1962, s.236..

86 Erman Şener, Kurtuluş Savaşı ve Sinemamız, Dizi Yayınları, İstanbul, 1970, s. 35.

87 Burhan Arpad, "Atatürk Sevgisi” Sinema Tenkitleri, Vatan Gazetesi, 1 Mayıs 1954, s.4.

88 “Kendi aramızda,” Akis Dergisi, Sayı:26, 6 Kasım 1954, s.3. 
arkadaşı ve sadık halefi olarak tanıtmaktadır. Demokrat Parti'nin özellikle ekonomik icraatlarını da övmektedir.

"Atatürk Sevgisi” filmi, propaganda öğeleri taşımakla birlikte Demokrat Parti'nin Atatürk’e bakışını ve Atatürkçülük yorumu hakkında veriler de sunmaktadır. Çok Partili hayat ile ayrışan Demokrat Parti'nin merkez sağ Atatürkçülük yorumunun izlerini "Atatürk Sevgisi” filminde görmek mümkündür. Belgesel filmin dili, Demokrat Parti’nin millete mal olmamış inkılâplar arasında gördüğü dilde sadeleşmeye karşı tutumuyla paraleldir. Belgeselde birçok kelimenin eski dildeki karşılığının kullanıldığı dikkat çekmektedir. Örneğin, Başvekil, Reisicumhur, Teşrinevvel gibi. Film, Atatürk'ün üstün yetenekli bir lider ve kahraman olarak özellikle Milli Mücadelede tek başına ülkeyi kurtardığını anlatır. Filmin tamamında resmigeçitlere mahsus şiirsel ve hamasi bir dil mevcuttur. Cumhuriyetin ilanı ile sonuçlanan Milli Mücadele döneminin anlatıldığı bölümde, Demokrat Parti’nin rakibi İsmet İnönü'nün baskın rol oynadığı İnönü Savaşları ve Lozan Antlaşmasına değinilmemiştir. Filmde Atatürk, "Türk’ün ve insanlığın eşsiz adamı," "Türk tarihinin büyük evladı," "Dünyaya eşi gelmemiş kumandan” olarak övülmüştür. Ancak bu övgüler, Atatürk'ün ölümünden sonraki bölümde yer alan ve yaklaşık altı dakika süren mersiyeye göre siradan kalır.

Cumhuriyetin ilanına kadar “Atatürk Sevgisi,” filmi resmi tarih anlatısını takip eder. Bu noktadan itibaren Atatürkçülüğün sağ yorumunun etkisi daha güçlü bir şekilde kendini hissettirir. Filmde, "Birbirini takip eden inkılâplar arasında Türkiye Cumhuriyeti Onuncu yılını idrak etti" ifadesi dışında inkılâplara değinilmemiştir. Bir cümle içinde inkılâplar geçiştirilmiştir. İnkılâplardan bahsetmeyen film, tören görüntülerine ve nutuklara yer vermiştir. Demokrat Parti, millete mal olmuş/olmamış inkılâplar ayrımı yapmıştır. Ancak filmde hiçbir inkılâptan söz edilmemektedir. Elbette bu durum, Demokrat Parti'nin inkılâplara tümden karşı olduğu anlamını çıkartmaya yetmez. İktidarı boyunca karş1-devrim olarak anılabilecek hareketlere müsamaha göstermeyen Demokrat Parti, inkılâplara muhalif değildir. İnkılâplar gibi "netameli” olarak görülen konulara girilmemesi "Atatürk Sevgisi” filminin bir seçim çalışması olmasından kaynaklanabilir. Popülist kaygının neticesinde inkılâplar üstü kapalı bir şekilde geçilmiştir.

Film, Demokrat Parti'nin Atatürk’ün mali mirası ile ilgili görüşünü yineler. Atatürk’ün mirasını Türk milletine bıraktığını öne sürerek Demokrat Parti, Cumhuriyet Halk Partisinin mallarına el konulmasını ve hazineye devredilmesini kararlaştıran tasarıyı Meclis’te yasalaştırmıştı. Yasadan kısa bir süre sonra hazırlanan fillmde, Atatürk'ün mirasını Türk milletini bıraktığı özellikle vurgulanmıştır. Filmde, Demokrat Parti döneminde gerçekleşen Atatürk'ün Naaşının Anıtkabir'e Nakil Töreni görüntülerine yer verilir. Törende, Cumhurbaşkanı Celal Bayar’ın yaptığı konuşma filmde kesintisiz yer alır. Celal Bayar konuşmasında; "Atatürk! Sen bizdendin. Seni halife yapmak, padişah yapmak isteyenler oldu, iltifat etmedin. Milli irade yolunu seçtin. Hayat ve şahsiyetini milletinin hizmetine vakfettin. Türk'ün gipta ettiği, taziz ettiği, övdüğü ve övündüğ̈̈ vasıflara maliktin, bütün bu meziyetlerinle Türk'ün ta kendisiydi" diyerek "milli irade" vurgusu yapar.

Filmin son kısmına merkez-sağ Atatürkçü yorumun muasır medeniyet seviyesine ulaşma, modernleşme, ilerleme ülküsü damga vurur. Atatürk'e seslenilen bu bölümde ulaşım, maden, demir çelik, iplik, orman, tarım, denizcilik, ihracat ve savunma sanayi gibi farklı sektörlerde ilerleme ve gelişmeler anlatılır ve gösterilir. İktisadi kalkınma ve endüstrileşme icraatlarına yer verilir. Görüntüde ve metinde; Türk endüstrisi, fabrikalardan göklere yükselen dumanlar, işleyen tezgâhlar, ekilmiş tarlalar, çalışan madenler dikkat çeker. Filmdeki ifade ile "inşa devam etmektedir." 
İşçi kadınlar gösterilse dahi filmde odak noktası, kültürel modernleşme değil endüstrileşme ve sanayileşmedir. Kalkınma hamlelerinin ardındaki güç, Atatürk'ten ilham alan Demokrat Parti'dir. Nihayet Atatürk kabrinde müsterih uyuyabilir çünkü vatan Atatürk'ün emniyet ettiği ellerdedir. Atatürk'ün halefinin ve takipçisinin Demokrat Parti olduğunu vurgulayan bu söz ile film sona erer.

1954 Seçimlerinden evvel bir hafta sinemalarda gösterime giren "Atatürk Sevgisi" filminin ayrıca 1958 yılında Akdağmadeni Kalkındırma ve Tanıtma Cemiyeti tarafından halka bedava olarak gösterildiğine dair bir haber bulunmaktadır. ${ }^{89} 27$ Mayıs 1960 Askeri darbesinin ardından Demokrat Parti döneminin pek çok icraatı gibi "Atatürk Sevgisi” filmi de arşivin tozlu rafları arasında unutulmuştur. Yıllar sonra 10 Kasım 2008 tarihinde Türkiye İş Bankası Müzesinde gösterilmiş̧ ve "Atatürk Sevgisi” filminin unutulmuşluğu sona ermiştir.

\section{Sonuç}

Demokrat Parti, iktidarı boyunca Cumhuriyet Halk Partisi ile Atatürk arasındaki organik bağı yok etmeye çalışmıştır. İki parti arasında, Atatürk'e bağlılık üzerinden bir rekabet alanı yaratılmıştır. Demokrat Parti, Anıtkabir inşaatını tamamlayarak, Atatürk'ü Koruma Kanunu olarak tanınan yasal düzenlemeyi yaparak Atatürk'ü partiler üstü bir sembole dönüştürmüsşür. Demokrat Parti'nin partiler üstü Atatürk imajını destekleyen çalışmalarından biri de bir belgesel film olmuştur. "Atatürk Sevgisi" filmi, Demokrat Parti döneminde yapılan bir film olmaktan öte Demokrat Parti iktidarının yapımına karar verdiği ve finansmanını karşıladığı bir filmdir. Atatürk’ün hayatını anlatma iddiası filmi "ilk" ve "öncü” statüsüne yerleştirir. Atatürk'ün hayatına odaklanan arşiv görüntülerinden derlenen bir belgeseldir. Ancak belgesel, belirli bir tema çerçevesinde derin bir arşiv araştırması sonucu hazırlanmamıştır. Arşiv görüntülerinin gelişigüzel birleştirilmesi sonucu didaktik bir yapım ortaya çıkmıştır. "Atatürk Sevgisi” filmi, Atatürk'ün hayatından çok Celal Bayar'a ve Demokrat Parti'nin icraatlarına odaklanır. Filmde sunulan Atatürk'ün hayatı ve görüssleri merkez-sağ Atatürkçülük yorumudur. "Türk'ün ve insanlığın eşsiz adamı," "Türk tarihinin büyük evladı," "Dünyaya eşi gelmemiş kumandan" olarak övülen Atatürk, partiler üstü bir sembole dönüştürülmüştür. "Atatürk Sevgisi” filmi, merkez-sağ Atatürkçülüğün iktisadi kalkınma ülküsünü, muasır medeniyete ulaşma arzusunu vurgulamaktadır. Film, kültürel modernleşmeye değinmediği gibi Atatürk inkılaplarından hiç söz etmemektedir. 1954 Milletvekili Genel Seçimleri öncesi gösterime giren film, tartışmalı bir alan olarak gördüğü inkılaplardan söz etmemesi merkezsağ Atatürkçü görüşün popülist yönünün tezahürüdür. Demokrat Parti'nin Atatürk'ün sadık tek takipçisi olduğu mesajını verebilmek için tarihsel olgulara sadık kalınmamıştır. "Atatürk Sevgisi" filmi, Atatürk'ün hayatını anlatan öncü bir yapımdır ancak propagandayı aşamayan olumsuz bir örnek olarak belgesel film tarihine geçmiştir.

89 Milliyet Gazetesi, 15 Nisan 1958, s.3.

90 Cumhuriyet Gazetesi, 10 Kasım 2008, s.15. 


\section{Kaynakça}

\section{Cumhuriyet Arşivi}

Cumhuriyet Arşivi, 490-1-0-0/384-1625-2-s.3-4-5-6-16.

\section{Kitap ve Makaleler}

Ahmad Feroz, Demokrasi Sürecinde Türkiye 1945-1980, Çev: Ahmet Fehmi, Hil Yayın, İstanbul, 1996.

Albayrak Mustafa, "Kemalizm'in Düşünsel Temelleri ve Tarihsel Oluşumu," Atatürk Araştırma Merkezi Dergisi, Cilt: 26, Say1: 77, 2010, s.307-343.

Alpkaya Faruk, "Bir 20. Yüzyıl Akımı: Sol Kemalizm,” Modern Türkiye’de Siyasi Düşünce Cilt: 2 Kemalizm, İletişim Yayınları, İstanbul, 2006, s. 477-500.

Arpad Burhan, “Atatürk Sevgisi” Sinema Tenkitleri, Vatan Gazetesi, 1 Mayıs 1954, s.4.

Aytekin Hakan, Türkiye'de Toplumsal Değişme ve Belgesel Sinema, BSB Yayınları, İstanbul, 2017.

Bali Rifat, The Turkish Cinema In The Early Republican Years, The Isis Press, İstanbul, 2007.

Beyoğlu Süleyman, İmparatorluktan Cumhuriyete Türk Sineması (1895-1939), Dergâh Yayınları, İstanbul, 2018.

Bora Tanıl, “Celal Bayar,” Modern Türkiye’de Siyasi Düşünce Cilt: 2 Kemalizm, İletişim Yayınlar1, İstanbul, 2006, s. 546-554.

Bora Tanıl, “Celal Bayar,” Türkiye’nin 1950’li Yıllarl, Editör: Mete Kaan Kaynar, İletişim Yayınları, İstanbul, 2016, s.151-157.

Bora Tanıl ve Taşkın Yüksel, “Sağ Kemalizm,” Modern Türkiye'de Siyasi Düşünce Cilt: 2 Kemalizm, İletişim Yayınları, İstanbul, 2006, s. 529-545.

Bora Tanıl, “Adnan Menderes” Türkiye’nin 1950'li Yıllarl, Editör: Mete Kaan Kaynar, İletişim Yayınları, İstanbul, 2016, s. 331-347.

Boran Tunç, “Türk Sinema Tarihinden İlgi Çekici Bir İddianın İncelenmesi," Türk Sinema Tarihine Farklı Bakışlar, Detay Yayıncılık, Ankara, 2020, s.1-40.

Demirel Tanel, Türkiye’nin Uzun On Yll Demokrat Parti’nin İktidarl ve 27 Mayls, İstanbul Bilgi Üniversitesi Yayınları, İstanbul, 2016.

Dinç Enis, Performing Modernity: Atatürk On Film (1919-1938), University of Amsterdam, Yayınlanmamış Doktora Tezi, 2016.

Egeli Münir Hayri, Bilinmeyen Yönleriyle Atatürk, Berikan Yayınevi, Ankara, 2004.

Eroğul Cem, “Çok Partili Düzenin Kuruluşu 1945-1971," Geçiş Sürecinde Türkiye, Belge Yayınları, İstanbul, 1992, s. 112-158.

Eroğul Cem, Demokrat Parti Tarihi ve İdeolojisi, Yordam Kitap, İstanbul, 2019.

Ertan Temuçin F., "Beklentiler, Hayal Kırıklıkları ve Aydınlar (Kadro-Forum-Yön),” Türk 
Yurdu Dergisi, Cilt:18, Say1:134, Ekim 1998, s.145-149

Ertan, Temuçin F., "Kadro Dergisi Niçin Kapandı?” Atatürk Dergisi, Cilt:3, Sayı:4, Temmuz 2003, s.19-34.

Harun Kenan, “Ata'nın Emrindeki Adam Anlatıyor,” 20. Asır Dergisi, Sayı:13, 8 Kasım 1952, s.8,30.

Hinkle Eugene M., “Modern Türkiye’de Sinema,” Kebikeç Dergisi, Sayı:28, s.91-102.

İlhan Atilla, "Kemalizm Müdafaa-i Hukuk Doktrini," Modern Türkiye'de Siyasi Düşünce Cilt: 2 Kemalizm, İletişim Yayınları, İstanbul, 2006, s. 518-528.

Kabadayı Lale, Film Eleştirisi Kuramsal Çerçeve ve Sinemamızdan Örnek Çözümlemeler, Ayrıntı Yayınları, İstanbul, 2013.

Karacan Ali Naci, “Atatürk’ün Ruhu,” Milliyet Gazetesi, 8 Haziran 1950, s.1,5.

Karagözoğlu İnal, Ankara'da Sinemalar Vardı, Bileşim Yayınları, İstanbul, 2004.

Karpat Kemal, Türk Demokrasi Tarihi, İstanbul Matbaası, İstanbul, 1967.

Koçak Cemil, İkinci Parti Türkiye’de İki Partili Siyasi Sistemin Kuruluş Y1lları (1945-1950) Cilt 1, İletişim Yayınları, İstanbul, 2010.

Köker Levent, "Kemalizm/Atatürkçülük: Modernleşme, Devlet ve Demokrasi," Modern Türkiye’de Siyasi Düşünce Cilt: 2 Kemalizm, İletişim Yayınları, İstanbul, 2006, s. 97-112.

Lewis Bernard, Modern Türkiye’nin Doğuşu, Çev: Metin Kıratlı, TTK Basımevi, Ankara, 2007.

Onaran Âlim Şerif, Türk Sineması (Cilt 1), Kitle Yayınları, İstanbul, 1994.

Özden Zafer, Film Eleştirisi Film Eleştirisinde Temel Yaklaşımlar ve Tür Filmi Eleştirisi, İmge Kitapevi, Ankara, 2014.

Özön Nijat, İlk Türk Sinemacısı Fuat Uzkınay, Türk Sinematik Derneği Yayınları, İstanbul, 1970.

Özön Nijat, Türk Sineması Kronolojisi 1895-1966, Bilgi Yayınevi, İstanbul, 1968.

Özön Nijat, Türk Sinema Tarihi, Dünden Bugüne 1896-1960, Artist Yayınlar1, İstanbul, 1962.

Özuyar Ali, “Gazi’nin Sineması Köşk’ün Beyazperdesinde,” Atlas Tarih Kurtuluş Savaşı Özel Sayls1 2, 2020/01, s.116-123.

Özuyar Ali, Türk Sinema Tarihinden Fragmanlar (1896-1945), Phoenix Yayınevi, Ankara, 2013.

“Sunuş,” Modern Türkiye’de Siyasi Düşünce Cilt: 2 Kemalizm, İletişim Yayınları, İstanbul, 2006, s. 13-15.

Şarman Kansu, "1909-1919 Arşiv Fotoğraflarından Genç Mustafa Kemal," Atlas Tarih Kurtuluş Savaşı Özel Sayısı 2, Sayı 2020/01, s.24-31.

Şener Erman, Kurtuluş Savaşı ve Sinemamız, Dizi Yayınları, İstanbul, 1970.

Şeyhanlıoğlu Hüseyin, “Demokrat Parti Döneminde Türkiye’de Kültürel Faaliyetler (1946- 
1960)," Tarih ve Gelecek Dergisi, Cilt 6, Sayı 4, Aralık 2020, s.1369-1384.

TBMM Zabıt Ceridesi, Devre 4, İçtima 2, 1 Kasım 1932, Cilt:10, s.3.

Ufuk Adnan, "Uyuyan Sinema,” Yeditepe Gazetesi, Say1:123, 15 Ocak 1957, s:1-6.

Ünder Hasan, "Atatürk İmgesinin Siyasal Yaşamdaki Rolü," Modern Türkiye'de Siyasi Düşünce Cilt: 2 Kemalizm, İletişim Yayınları, İstanbul, 2006, s. 138-155.

Varel Anı1, "Ellili Yıllarda Muhalefet: Hükümete Yönelik Temel Eleştiriler ve DP Karşısında CHP'nin İdeolojik Konumlanış1,' Türkiye ’nin 1950'li Yılları, Editör: Mete Kaan Kaynar, İletişim Yayınları, İstanbul, 2016, s. 203-234.

Yalman Ahmet Emin, Yakın Tarihte Gördüklerim, Geçirdiklerim Cilt 1, Pera Turizm ve Ticaret A.Ş, 1997.

Zürcher Erik Jan, Modernleşen Türkiye’nin Tarihi, Çev: Yasemin Saner Gönen, İletişim Yayınları, İstanbul, 2007.

\section{Dergi ve Gazeteler}

Akis Dergisi

Cumhuriyet Gazetesi

Milliyet Gazetesi

Ulus Gazetesi

Vatan Gazetesi

Yeditepe Gazetesi

Yeni Ulus Gazetesi

Zafer Gazetesi 